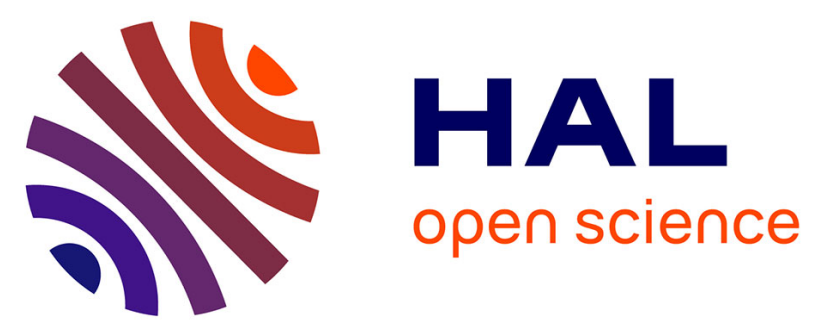

\title{
Effect of TiC incorporation on the optical properties and oxidation resistance of $\mathrm{SiC}$ ceramics
}

Héléne Arena, Moustapha Coulibaly, Audrey Soum-Glaude, Alban Jonchere, Guilhem Arrachart, Adel Mesbah, Nicolas Pradeilles, Marion Vandenhende, Alexandre Maître, Xavier Deschanels

\section{To cite this version:}

Héléne Arena, Moustapha Coulibaly, Audrey Soum-Glaude, Alban Jonchere, Guilhem Arrachart, et al. Effect of $\mathrm{TiC}$ incorporation on the optical properties and oxidation resistance of $\mathrm{SiC}$ ceramics. Solar Energy Materials and Solar Cells, 2020, 213, pp.110536. 10.1016/j.solmat.2020.110536 . hal03005934

\section{HAL Id: hal-03005934 \\ https://hal.science/hal-03005934}

Submitted on 24 Nov 2020

HAL is a multi-disciplinary open access archive for the deposit and dissemination of scientific research documents, whether they are published or not. The documents may come from teaching and research institutions in France or abroad, or from public or private research centers.
L'archive ouverte pluridisciplinaire HAL, est destinée au dépôt et à la diffusion de documents scientifiques de niveau recherche, publiés ou non, émanant des établissements d'enseignement et de recherche français ou étrangers, des laboratoires publics ou privés. 


\section{Effect of TiC incorporation on the optical properties and the oxidation resistance of $\mathrm{SiC}$ ceramics}

Hélène Aréna $^{1 *}$, Moustapha Coulibaly $^{1}$, Audrey Soum-Glaude ${ }^{2}$, Alban Jonchère ${ }^{1}$, Guilhem Arrachart $^{1}$, Adel Mesbah ${ }^{1}$, Nicolas Pradeilles ${ }^{3}$, Marion Vandenhende ${ }^{3}$, Alexandre Maître ${ }^{3}$, and Xavier Deschanels ${ }^{1}$

${ }^{1}$ ICSM, CEA, CNRS, ENSCM, Univ. Montpellier, Marcoule, 30207 Bagnols-sur-Cèze, France ${ }^{2}$ PROMES-CNRS, UPR 8521, 7 rue du Four Solaire 66120 Font-Romeu Odeillo Via, France ${ }^{3}$ IRCER, UMR CNRS 7315, 87068 Limoges, France

\section{Corresponding authors: $\underline{\text { helene.arena@ cea.fr and xavier.deschanels@ cea.fr }}$}

Keywords: SiC, TiC, nano composite, oxidation resistance, optical properties, CSP, high temperature, ceramics, reflectance.

(1)

\section{Abstract}

In concentrating solar power (CSP) technologies, the absorber material should be spectrally selective under severe operating conditions, i.e. $\sim 1000^{\circ} \mathrm{C}$ under air atmosphere. SiC-TiC nanocomposites could be good candidates for this application due to their spectral selectivity at room temperature, but their behavior under CSP operating conditions is unknown. Therefore, the spectral selectivity and oxidation resistance of TiC-SiC composites were studied up to 500 ${ }^{\circ} \mathrm{C}$, under air, for various compositions. During heating, the emittance increased with the temperature. After heating, the $\mathrm{TiC}$ grains at the surface were oxidized into $\mathrm{TiO}_{2}$, while $\mathrm{SiC}$ grains showed good behavior. However, despite little oxidation, the spectral selectivity of the nanocomposites remained interesting after heating. Specific oxidation tests up to 9 days at $1000^{\circ} \mathrm{C}$ under air showed an increase of the oxidation resistance with the amount of SiC. This result is the consequence of the formation of a protective layer of $\mathrm{SiO}_{2}$ preventing the oxidation of the TiC grains. The composition 30 at $\% \mathrm{TiC}-70$ at\% $\mathrm{SiC}$ seems to be a good compromise between low oxidation and good selectivity. 

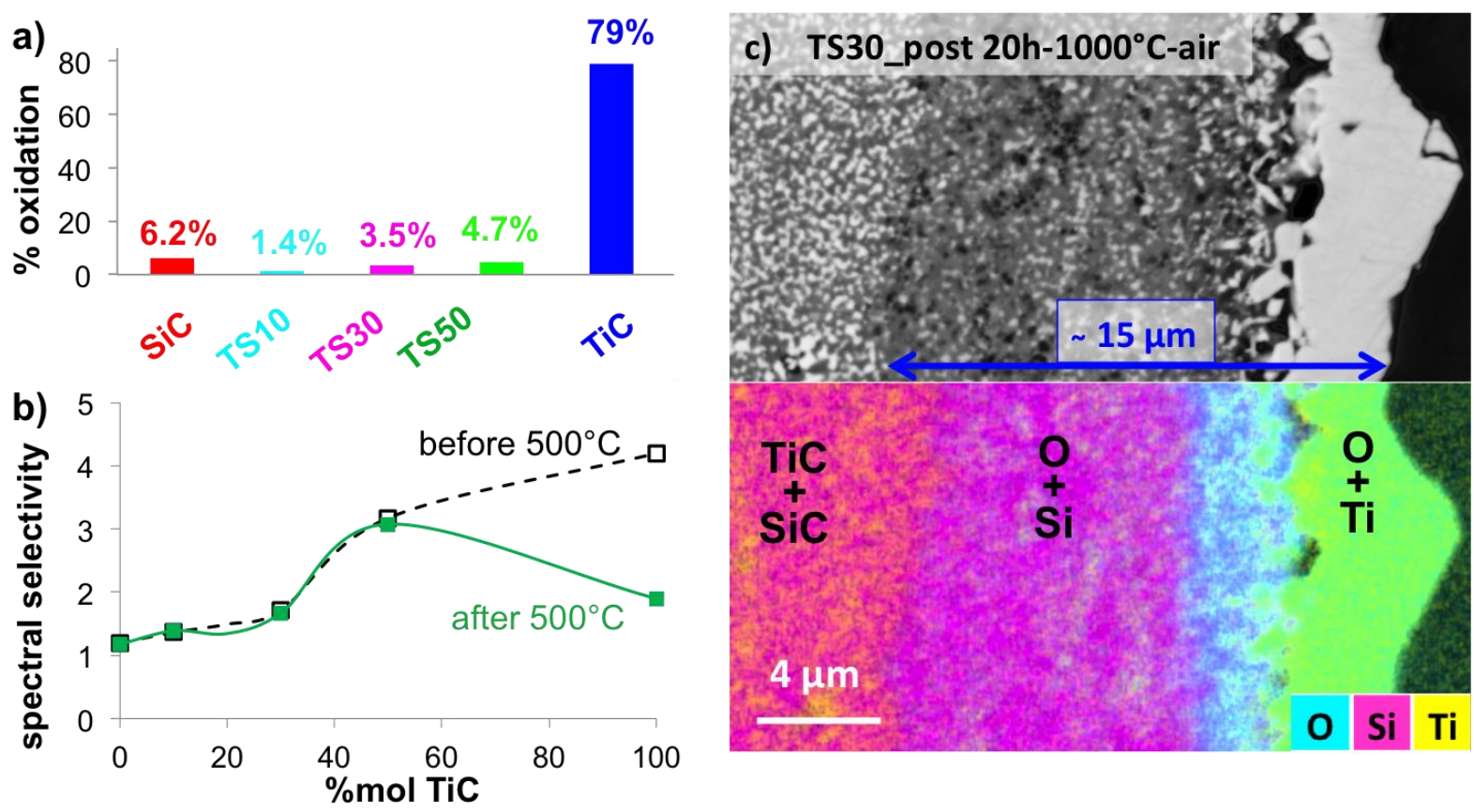

\section{Introduction}

Solar energy is a powerful source of renewable energy which can be efficiently exploited by Concentrating solar power technologies (CSP) [1, 2]. In this promising and sustainable systems, the sunlight is collected by several heliostats and concentrated towards the absorber. The absorber converts the solar radiation into heat and transfers it to a thermal fluid, which will drive a turbine in power block to generate electricity. However, when heated by sunlight, the absorber may behave as a blackbody and lose some energy by thermal emission. To maximize its efficiency, the ideal absorber should be spectrally selective, i.e., have a high absorptance in the sunlight region $(0.25-2.5 \mu \mathrm{m})$ and a low infrared emittance in the blackbody region (typically $1.25-25 \mu \mathrm{m}$ at $500{ }^{\circ} \mathrm{C}$ ) [3-6]. The Carnot efficiency of the solar thermal power plants increases when increasing the working temperature $[7,8]$. Therefore, the absorber must also be able to maintain good mechanical, physical and chemical properties under severe operating conditions $\left(\mathrm{T} \sim 1000{ }^{\circ} \mathrm{C}\right.$ under air atmosphere).

Silicon carbide $(\mathrm{SiC})$ is the material commonly used as the absorber because of its high resistance to oxidation and its good sunlight absorptance. The surface oxidation of $\mathrm{SiC}$ leads to the formation of an amorphous $\mathrm{SiO}_{2}$ passivating layer. This $\mathrm{SiO}_{2}$ layer protects the $\mathrm{SiC}$ underneath up to temperatures of $1400{ }^{\circ} \mathrm{C}$ [7]. However, $\mathrm{SiC}$ has a high thermal emittance leading to significant energy losses in the infrared region, especially when increasing the working temperatures $[9,10]$. 
Thanks to their spectral selectivity, metal borides, nitrides or carbides could be good candidates for solar absorber applications [11-24]. In addition, these materials have extremely high thermal stability, good thermo-chemical and thermo-mechanical properties, high hardness, high electrical and thermal conductivities [25-28]. Coulibaly et al. compared the optical properties of several carbides and demonstrated that titanium carbide (TiC) is one of the best compound in this group, due to its particularly low emittance [29]. However, the major limitation of this material is its low resistance to oxidation [30-37].

To improve both the optical selectivity of $\mathrm{SiC}$ and the oxidation resistance of $\mathrm{TiC}$, they can be combined in a nanocomposite structure [29, 38]. Indeed, the association of $\mathrm{SiC}$ and $\mathrm{TiC}$ showed better optical selectivity than pure $\mathrm{SiC}$ and better oxidation resistance than pure $\mathrm{TiC}$. According to Banu et al., the oxidation of a TiC/SiC composite material produced $\mathrm{TiO}_{2} / \mathrm{SiC}$ up to $750{ }^{\circ} \mathrm{C}$, and $\mathrm{TiO}_{2} / \mathrm{SiO}_{2} / \mathrm{SiC}$ mixture at higher temperatures [39]. The addition of $\mathrm{SiC}$ increased the oxidation resistance of $\mathrm{ZrC}$ [40], $\mathrm{ZrB}_{2}$ and $\mathrm{HfB}_{2}$ materials [26, 41].

In a previous paper [38], we have shown how the porous characteristics (density and surface roughness) can change the selectivity of $\mathrm{SiC} 70 \%$ at. $-\mathrm{TiC} 30 \%$ at. nanocomposite at room temperature. In this paper, we studied the mutual dependency between the TiC content, the oxidation resistance and the spectral selectivity by reflectance measurements at various temperatures up to $500{ }^{\circ} \mathrm{C}$, and thorough material characterization. To go further on the assessment of the oxidation resistance, the samples were also heated to $1000{ }^{\circ} \mathrm{C}$ under air during $20 \mathrm{~h}$ to 9 days to precise the nature of the oxide layers.

\section{Experimental}

The complete synthesis route, starting materials, sample preparation and characterization techniques used are described in detail in Supplementary Information (SI 1) and in our previous paper [38]. The main information are given below.

A "molecular route" involving hydrolysis and polycondensation of alkoxides as metal oxide precursors, and sucrose and citric acid as carbon sources was used to synthesize the nanocomposites [42]. Two heat treatments were used to transform the resulting oxide powders into carbides; the decomposition of the organic part into carbon $\left(800{ }^{\circ} \mathrm{C}-4 \mathrm{~h}\right.$ - under $\left.\mathrm{Ar}\right)$, and then, the carbothermal reduction $\left(1550{ }^{\circ} \mathrm{C}-4 \mathrm{~h}-\right.$ under Ar). Composites with increasing $\mathrm{Ti} / \mathrm{Si}$ proportions were produced by this molecular synthesis route and commercial powders were used for the pure $\mathrm{TiC}$ and $\mathrm{SiC}$ reference samples (Table 1). Dense materials were produced by 
Spark Plasma Sintering (Syntex, Dr. Sinter 825, Japan), with sintering temperatures of $1700^{\circ} \mathrm{C}$ for $\mathrm{TiC}, 1950^{\circ} \mathrm{C}$ for $\mathrm{SiC}$ and $1750^{\circ} \mathrm{C}$ for the composites. The densified materials were mirror polished (Beta Buehler grinder-polisher), using SiC grinding papers and $1 \mu \mathrm{m}$ diamond paste (Struers). The samples density and porosity was evaluated using Archimedes method, helium pycnometry and the proportions of $\mathrm{Ti}, \mathrm{Si}, \mathrm{O}$ and $\mathrm{C}$ determined by elemental analysis $(\mathrm{C}$ and $\mathrm{O}$ wt\% - LECO CS230 and TCH600), and X-Ray Fluorescence (Spectro-Xepos).

\begin{tabular}{|c|c|c|c|c|c|}
\hline Sample name & TS10 & TS30 & TS50 & TiC & SiC \\
\hline Origin & \multicolumn{2}{|c|}{ Sol-gel synthesis route } & \multicolumn{2}{c|}{ Commercial products } \\
\hline $\mathbf{T i} / \mathbf{S i}(\% \mathbf{a t})$ & $10 / 90$ & $30 / 70$ & $50 / 50$ & $100 / 0$ & $0 / 100$ \\
\hline $\mathbf{T i} / \mathbf{S i}(\% \mathbf{w t})$ & $14.3 / 85.7$ & $39 / 61$ & $60 / 40$ & $100 / 0$ & $0 / 100$ \\
\hline Tsintering $\left({ }^{\circ} \mathbf{C}\right)$ & \multicolumn{3}{|c|}{1750} & 1700 & 1950 \\
\hline
\end{tabular}

Table 1: Name, composition and sintering temperature for all samples. "TS" refers to TiC-SiC composite materials, the number across refers to the at\% of TiC. For example, TS10 = $10 \%$ at TiC-90\%at SiC.

All samples were characterized in terms of: (i) roughness by optical interferometry (Fogale Nanotech), (ii) morphology and composition by Scanning Electron Microscopy (SEM - FEI Quanta 200 ESEM) coupled with Energy Dispersive X-ray Spectrometry (EDX - Bruker SDD 5030 detector), (iii) structure by X-Ray Diffraction (XRD) and Grazing Incident X-Ray

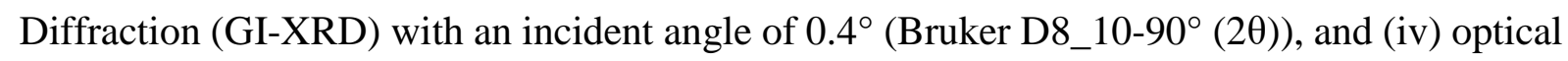
properties through the measurement of the reflectance in the 0.25 to $25 \mu \mathrm{m}$ range of wavelengths (Perkin Elmer Lambda 950 with a $150 \mathrm{~mm}$ integrating sphere coated with Spectralon, and a SOC-100 HDR coated with gold and using a $700{ }^{\circ} \mathrm{C}$ (973 K) blackbody). A heating plate on the sample holder enabled measurements at different temperatures (from room temperature to $500{ }^{\circ} \mathrm{C}$ ). The temperature of the sample was controlled by a surface thermocouple connected to PID (proportional-integral-derivative) regulation of the heating resistance. The complete description of the devices used for reflectance measurements is detailed in $[43,44]$. The absorptance $(\alpha)$, i. e. the propensity of the material to absorb sunlight, was calculated in the range of wavelengths $(\lambda) 0.25$ to $4 \mu \mathrm{m}$, from the total spectral reflectance $R\left(\lambda, T_{a}\right)$ measured at room temperature $\left(T_{a}\right)$, and the standard solar irradiance spectrum $G(\lambda)$, according to Equation 1. The directional emittance $\left(\varepsilon_{8^{\circ}}\right), i$. e. the tendency of the material to emit thermal radiations, was calculated in the range of wavelengths 1.25 to $25 \mu \mathrm{m}$, from the total spectral reflectance $R\left(\lambda, T_{a}, 89\right.$ measured at various temperatures $(T)$, and the spectral exitance of a blackbody $P(\lambda, T)$ at the same temperatures, derived from Planck's law (Equation 
117 2). Since all samples were completely opaque, the transmittance was not calculated and 118 considered null. The total spectral reflectance was measured at various detection angles ( $\theta$ from 1198 to $\left.80^{\circ}\right)$ to calculate the hemispherical emittance $\left(\varepsilon_{H}\right)$ at room temperature (Equation 3).

120

$$
\alpha=\frac{\int_{0.25 \mu m}^{4 \mu m}\left[1-R_{8^{\circ}}\left(\lambda, T_{a}\right)\right] \cdot G(\lambda) \cdot d \lambda}{\int_{0.25 \mu m}^{4 \mu m} G(\lambda) \cdot d \lambda} \quad \text { (1) } \quad \varepsilon_{\theta}(\theta, T)=\frac{\int_{1.25 \mu m}^{25 \mu m}[1-R(\lambda, T, \theta)] \cdot P(\lambda, T) \cdot d \lambda}{\int_{1.25 \mu m}^{25 \mu m} P(\lambda, T) \cdot d \lambda}
$$

$$
\varepsilon_{H}\left(T_{a}\right)=2 \int_{0}^{\pi / 2} \varepsilon_{\theta}\left(\theta, T_{a}\right) \cdot \sin \theta \cdot \cos \theta \cdot d \theta
$$

123 To measure the near-normal spectral reflectance at various temperatures, the samples were 124 heated up to $500{ }^{\circ} \mathrm{C}\left(450{ }^{\circ} \mathrm{C}\right.$ for TS30) as described in Figure 1 [44]. The atmosphere was not controlled during heating therefore the samples were submitted to oxidation. The samples were thoroughly characterized at room temperature before and after heating, using various techniques (SEM, (GI)XRD, and interferometry) to evaluate the effects of heating.

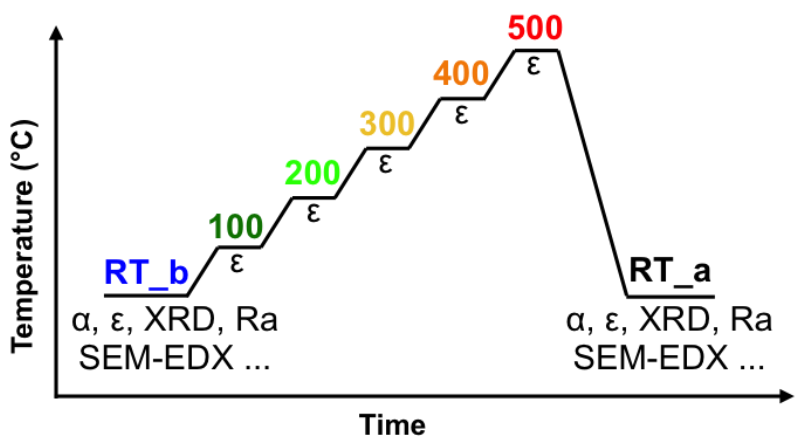

Figure 1: Heating procedure to measure the near-normal spectral reflectance at various temperatures. In the case of TS30, the maximum temperature was $450^{\circ} \mathrm{C}$.

133 Finally, thermogravimetric analyses (TGA) were conducted (Setsys 1750Cs Evol Staram). The 134 oxidation resistance of all samples was evaluated when exposed to $20 \mathrm{~h}$ dwell at $1000{ }^{\circ} \mathrm{C}$ under 135 air $\left(10^{\circ} \mathrm{C} \cdot \mathrm{min}^{-1}\right.$ rise and $30^{\circ} \mathrm{C} \cdot \mathrm{min}^{-1}$ decrease $)$.

\section{Results}

\subsection{Materials characterization before heating} Physical shape

140 The composition and the characterisitics of the sintered materials are reported in Table 2. All 141 samples except pure $\mathrm{SiC}$ had a relative density higher than $90 \%$ and a surface roughness lower 
142 than or equal to $10 \mathrm{~nm}$. Pure SiC sample presented a lower relative density $(74 \%)$ due to is

143 high covalency of the Si-C bonds which induces low self-diffusion coefficient $[45,46]$. The

$144 \mathrm{SiC}$ sample presented $26 \%$ of open porosity which resulted in surface holes partly accounted

145 when measuring the surface roughness $(24 \mathrm{~nm})$. On the contrary, TiC sample was more easily

146 densified due to the presence of Ti-Ti metallic bonds in the structure. The association of TiC

147 with $\mathrm{SiC}$ in a composite made the sintering easier compared to pure $\mathrm{SiC}$ and lead to denser and

148 denser materials as the proportion of TiC increased.

149 According to SEM-EDX and XRF analyses, the composites had the expected Ti/Si propotions,

150 also a little enrichement in Ti was observed for TS10 and TS50 samples. The O content was

151 high in sample TS30 (5.5 wt\%), even though the C content was equal to the amount required

152 for stoichiometric SiC-TiC materials. This result suggests an incomplete carbothermal

153 reduction, possibly due to a lack of homogeneization during the synthesis.

\begin{tabular}{|c|c|c|c|c|c|c|c|c|c|c|c|}
\hline \multirow{3}{*}{ Sample } & \multirow{3}{*}{\begin{tabular}{|c|}
$\begin{array}{c}\text { Processing } \\
\text { parameters }\end{array}$ \\
T sintering \\
$\left({ }^{\circ} \mathrm{C}\right)$
\end{tabular}} & \multicolumn{6}{|c|}{ Composition } & \multicolumn{4}{|c|}{ Sintered materials characteristics } \\
\hline & & \multicolumn{4}{|c|}{$\mathrm{Ti} / \mathrm{Si}(\mathbf{a t} \%)$} & \multirow{2}{*}{$\begin{array}{c}\mathrm{C} \\
(\mathrm{wt} \%)\end{array}$} & \multirow{2}{*}{$\begin{array}{c}\mathrm{O} \\
(\mathrm{wt} \%)\end{array}$} & \multirow{2}{*}{$\begin{array}{c}\text { Relative } \\
\text { density } \\
(\%)\end{array}$} & \multirow{2}{*}{$\begin{array}{c}\text { Open } \\
\text { porosity } \\
(\%)\end{array}$} & \multirow{2}{*}{$\begin{array}{c}\text { Closed } \\
\text { porosity } \\
(\%)\end{array}$} & \multirow{2}{*}{$\begin{array}{l}\text { Surface } \\
\text { roughne } \\
\text { ss }(\mathbf{n m})\end{array}$} \\
\hline & & Theory & $\mathrm{XRF}$ & $\begin{array}{l}\text { SEM- } \\
\text { EDX }\end{array}$ & Average & & & & & & \\
\hline TS10 & \multirow{3}{*}{1750} & $10 / 90$ & $12 / 88$ & $14 / 86$ & $13 / 87$ & 29.78 & 0.79 & 92.8 & 4.2 & 3 & 4 \\
\hline TS30 & & $30 / 70$ & $35 / 65$ & $28 / 72$ & $32 / 68$ & 25.99 & 5.5 & 95.8 & 1.2 & 3.1 & 10 \\
\hline TS50 & & $50 / 50$ & $55 / 45$ & $53 / 47$ & $54 / 46$ & 22.6 & 1.89 & 99.7 & 0 & 0.3 & 3 \\
\hline $\mathrm{TiC}$ & 1700 & $100 / 0$ & & & & 19.6 & 0.46 & 96 & 1.2 & 2.8 & 9 \\
\hline $\mathrm{SiC}$ & 1950 & $0 / 100$ & & & & 30.38 & 0.2 & 73.9 & 26.1 & 0 & 24 \\
\hline
\end{tabular}

Table 2: Characteristics of all samples after sintering. The theoretical wt\% of C is $30 \%, 29 \%, 26 \%, 24 \%$ and $20 \%$ for pure SiC, TS10, TS30, TS50 and pure TiC, respectively. The standard errors are evaluated at 1 at\% for

Ti/Si proportion, $1 \mathrm{~nm}$ for surface roughness and $0.1 \%$ for elemental analyses, relative density, and open and

162 Scanning Electron Microscopy was used to characterize the composition and the morphology

163 of the sintered materials (Figure 2). In back-scattering electron mode, the TiC grains appear

164 white, while the $\mathrm{SiC}$ matrix is gray. The size of the $\mathrm{TiC}$ grains is similar in all composite samples (about $150 \mathrm{~nm}$ ) and their repartition is homogenous at a short range. Nevertheless, 
166 when the TiC proportion increases (TS10 to TS30), the space between two TiC grains decreases 167 and large TiC enriched domains are observed. In the TS50 sample, the TiC and SiC contents 168 form two distinct domains with adjacent grains gathered in aggregates. In addition, all 169 composites present large areas with variations in electronic contrast, which could be explained 170 by local changes in porosity or composition. Here again, a better homogeneization of the 171 precursors during the synthesis could improve the $\mathrm{Ti}$ - Si repartition; ongoing work is in 172 progress to improve the mixing. In the case of the pure TiC sample, the grains are very small $173(<100 \mathrm{~nm})$ without any apparent porosity, while the pure $\mathrm{SiC}$ sample presents much bigger 174 grains (about $5 \mu \mathrm{m}$ ) and the open porosity is evidenced by the presence of holes. The bigger 175 grain size for pure $\mathrm{SiC}$ could be due to its higher sintering temperature $\left(1950{ }^{\circ} \mathrm{C}\right.$ vs $1750{ }^{\circ} \mathrm{C}$ for 176 composites) and/or to the starting powders. Indeed, the composites were synthesized by the 177 molecular route while the pure $\mathrm{TiC}$ and $\mathrm{SiC}$ originated from commercial powders.
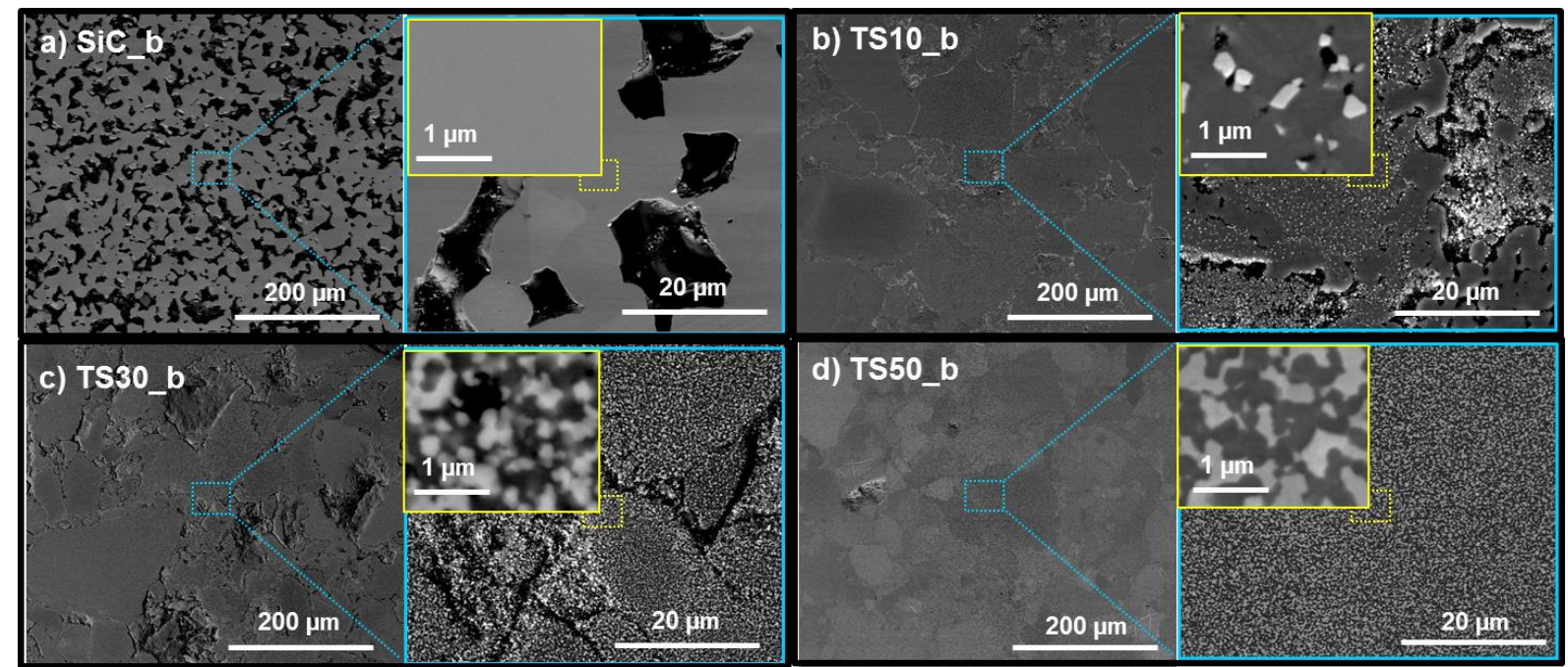

d) TS50_b
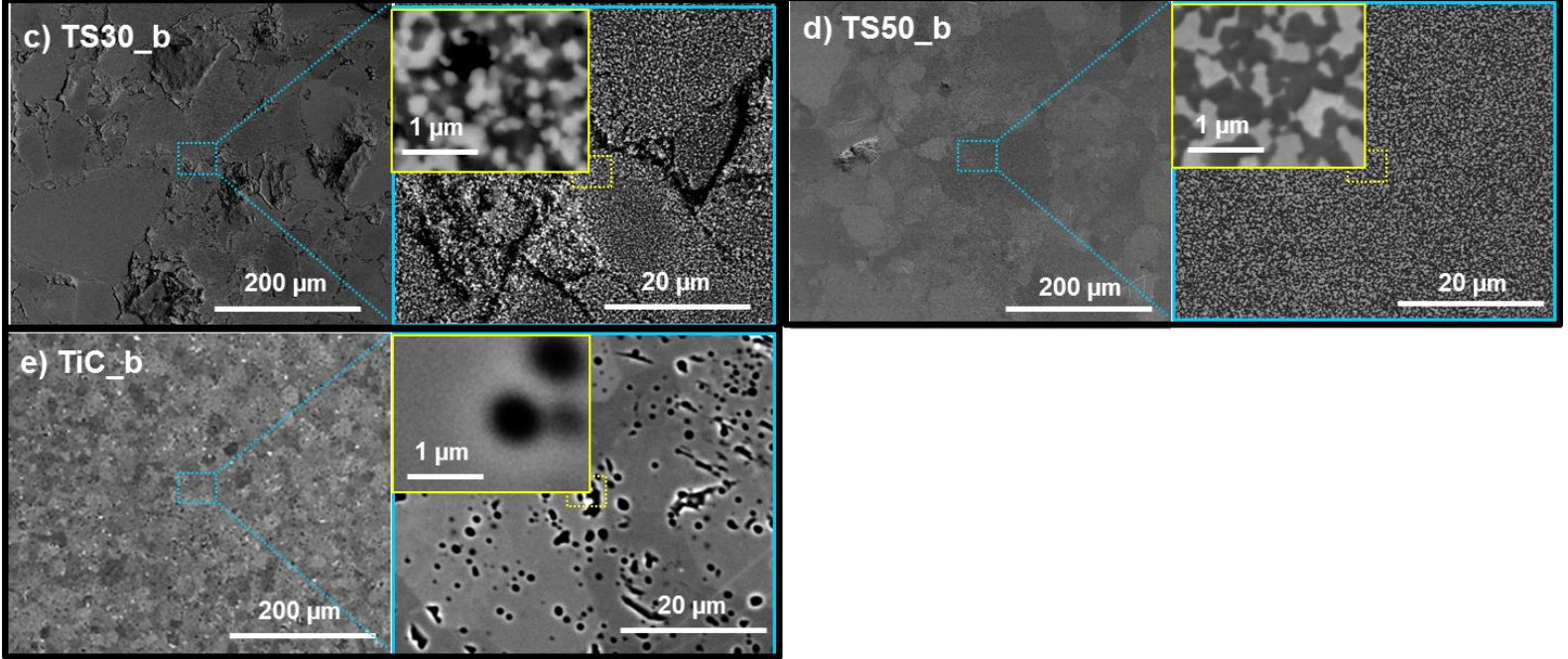

179 Figure 2: SEM images of the surface of the samples a) pure SiC, b) TS10, c) TS30, d) TS50, e) pure TiC. The “_b"

180 stands for "before heating". Based on SEM images, the grain size was measured on several grains and locations,

181 and a statistical average was considered.

182 The structure of the sintered materials was analyzed by XRD and the cubic 3C SiC (F-43m

183 space group) and cubic TiC (Fm-3m space group) phases are identified (Figure 5 and SI 2). As

184 expected, when increasing the TiC content, the relative intensities of the SiC peaks decreases,

185 while those of the TiC peaks increases. 
187 The optical properties of the samples were evaluated by the measurement of the total (specular $188+$ diffuse) spectral reflectance in the 0.25 to $25 \mu \mathrm{m}$ wavelength range. At room temperature 189 (Figure 3 blue curves, and SI 3), the reflectance of the SiC sample is much lower than that of 190 TiC with a typical reflectance peak $(\sim 60 \%)$ around $12 \mu \mathrm{m}$. The reflectance curves of the TiC-

$191 \mathrm{SiC}$ composites are shaped like that of the $\mathrm{SiC}$ sample, with an increasing reflectance as the amount of TiC increases (SI 3).

193

\subsection{Materials characterization during and after heating}

195 Afterward, all samples were heated up to $500^{\circ} \mathrm{C}$, to measure their total near normal spectral 196 reflectance (heating procedure described in Figure 1). The reflectance curves obtained at several 197 heating temperatures are reported in Figure 3, where (RT_b) and (RT_a) represent the room 198 temperature measurements recorded before, and after heating, respectively. For all samples, 199 and in the entire range of wavelengths, the reflectance decreases when increasing the 200 temperature. In the case of pure $\mathrm{SiC}$, the reflectance curves before and after heating are almost 201 superimposable. On the contrary, for the TiC sample, the reflectance curve at $400{ }^{\circ} \mathrm{C}$ presents 202 a strong decrease in the wavelengths range below $10 \mu \mathrm{m}$. At $500^{\circ} \mathrm{C}$, this decrease in reflectance 203 goes on to the full range of wavelengths, and the reflectance curve presents oscillations. The 204 reflectance measured at room temperature after heating (RT_a) is very different from the one 205 measured before heating (RT_b), it is rather close to the one obtained at $500{ }^{\circ} \mathrm{C}$, with even 206 stronger oscillations. In the case of TS10 and TS30 composites, heating induces a decrease in 207 reflectance but the shape of the curve is conserved. For the TS50 sample, the reflectance 208 strongly decreases, particularly in the 0.25 to $10 \mu \mathrm{m}$ range of wavelengths. 

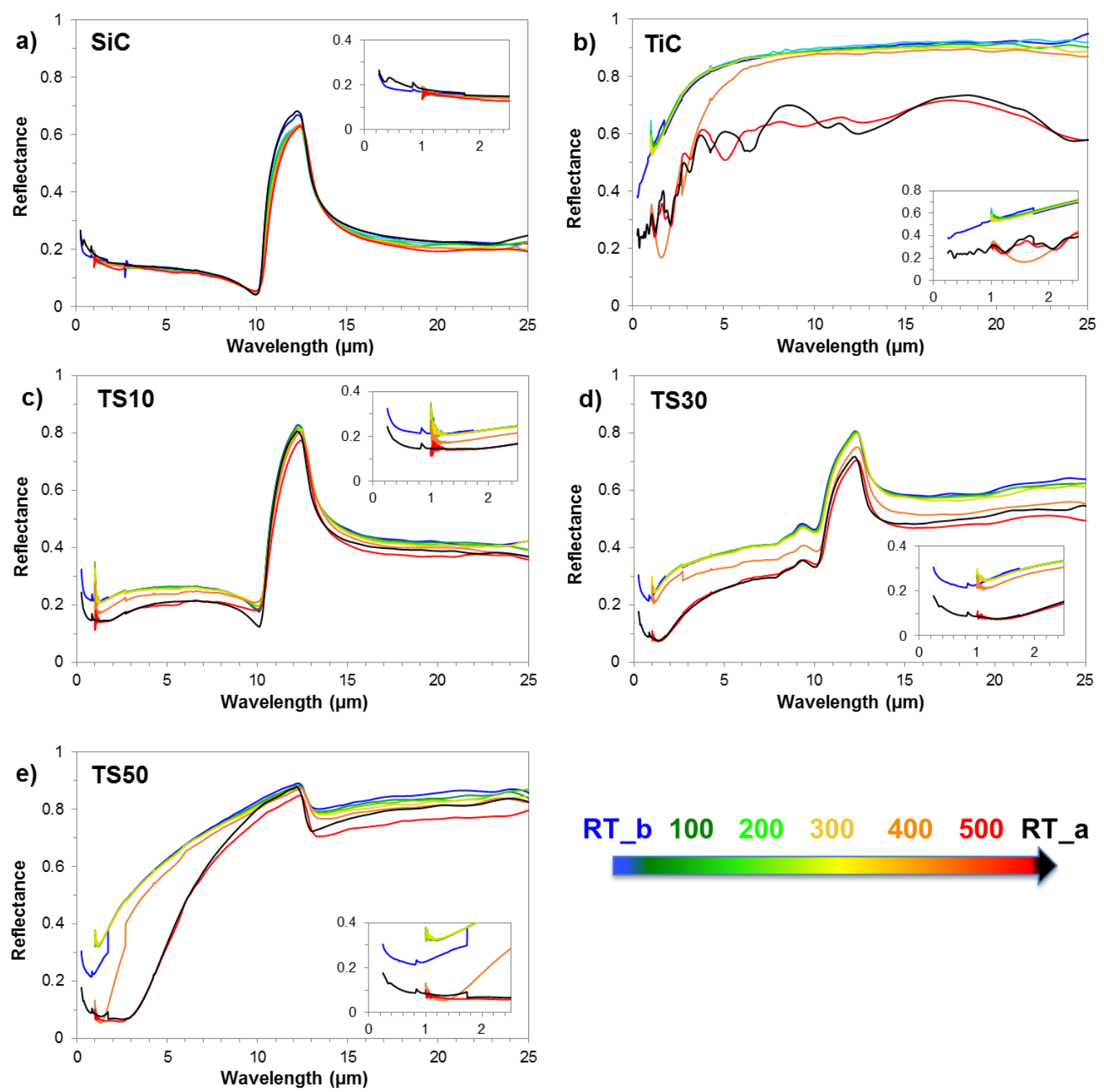

Figure 3: Near normal spectral reflectance at various temperatures $\left({ }^{\circ} \mathrm{C}\right)$ for a) pure $\left.\mathrm{SiC}, b\right)$ pure $\left.\mathrm{TiC}, \mathrm{c}\right) \mathrm{TS} 10$,

215 Surface characterization after heating provided explanations for these evolutions. For all 216 samples, the surface roughness has increased (from 4 to 38 for TS10, 10 to more than $550 \mathrm{~nm}$ 217 for TS30, 3 to $47 \mathrm{~nm}$ for TS50, 24 to $40 \mathrm{~nm}$ for SiC and 8 to $47 \mathrm{~nm}$ for TiC), which is confirmed 218 by SEM observations (Figure 4).

219 The surface of the pure SiC sample appears to be intact, while the presence of titanium oxides 220 is detected on the surface of all other samples. During their oxidation TiC grains expand by 221 volume gain and they emerge from the initially polished surface (Figure 4-a). To study the 222 thickness of the oxidized layer, sample pieces were embedded in a resin and polished (Figure 4-b). In the case of pure TiC sample, the surface is covered by a $2.3 \mu \mathrm{m}$ thick crust of titanium 
224 oxides with various morphologies. Underneath this zone, pristine TiC can be observed. In the 225 case of the composites TS50 and TS30, the cross-section observations show no demarcation, 226 indicating the presence of a significant layer of oxides on the surface of the sample. Only the 227 TiC grains of the surface are oxidized, the $\mathrm{SiC}$ matrix seems to be intact.

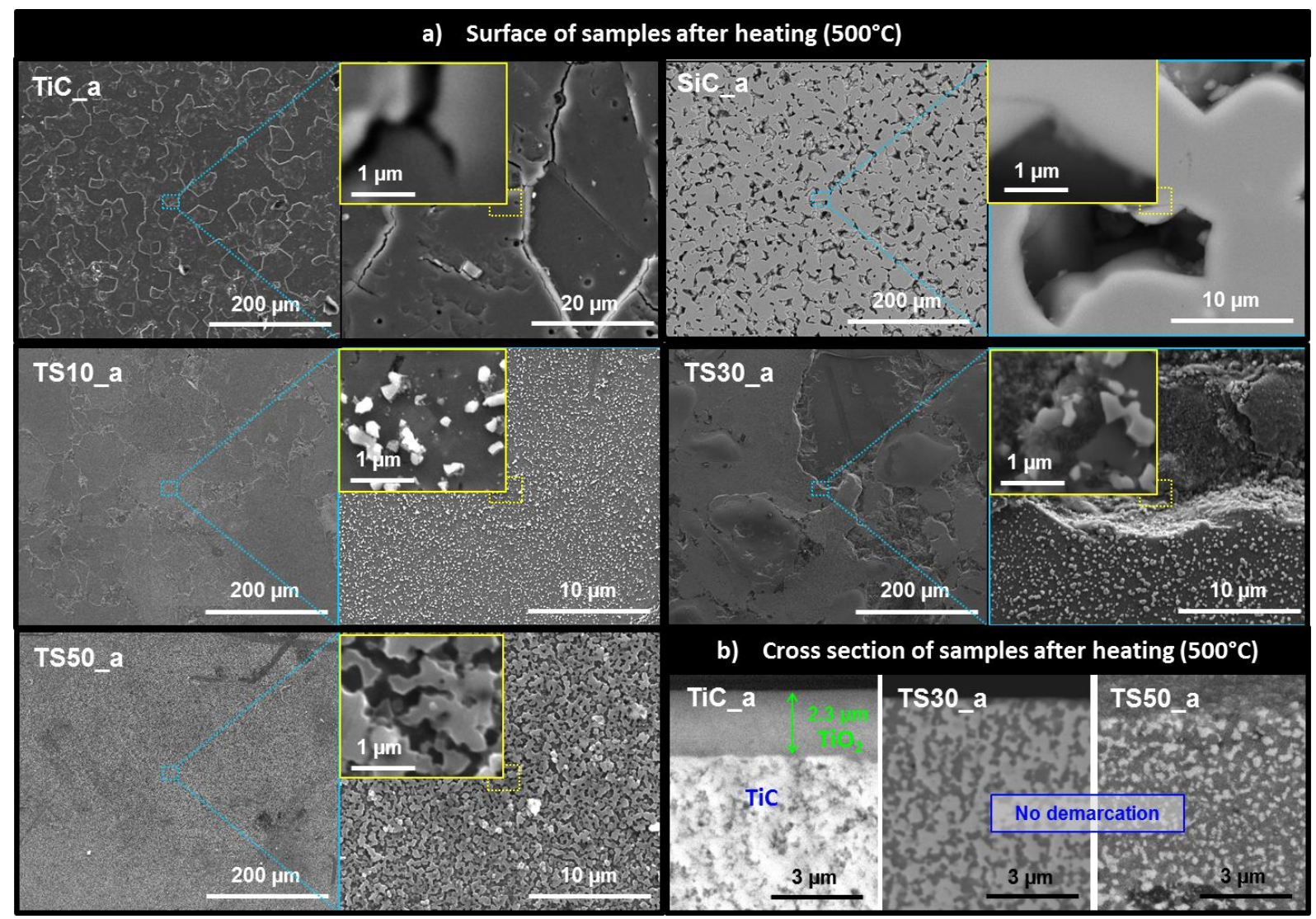

230 Figure 4: SEM observations after heating of a) surface of all samples and b) TiC, TS30 and TS50 in cross sections.

231 The “_a” stands for "after heating”.

233 The oxidation of $\mathrm{TiC}$ is also evidenced by the presence of the characterisic peaks of $\mathrm{TiO}_{2}$ in all 234 samples (GIXRD and XRD, Figure 6). At the extreme surface of the pure TiC sample, the 235 signature of $\mathrm{TiO}$ phase could be seen as well. In most cases, the $\mathrm{SiO}_{2}$ peaks are absent, 236 suggesting that $\mathrm{SiC}$ has not been oxidized, or that the resulting phase is not cristallized. 

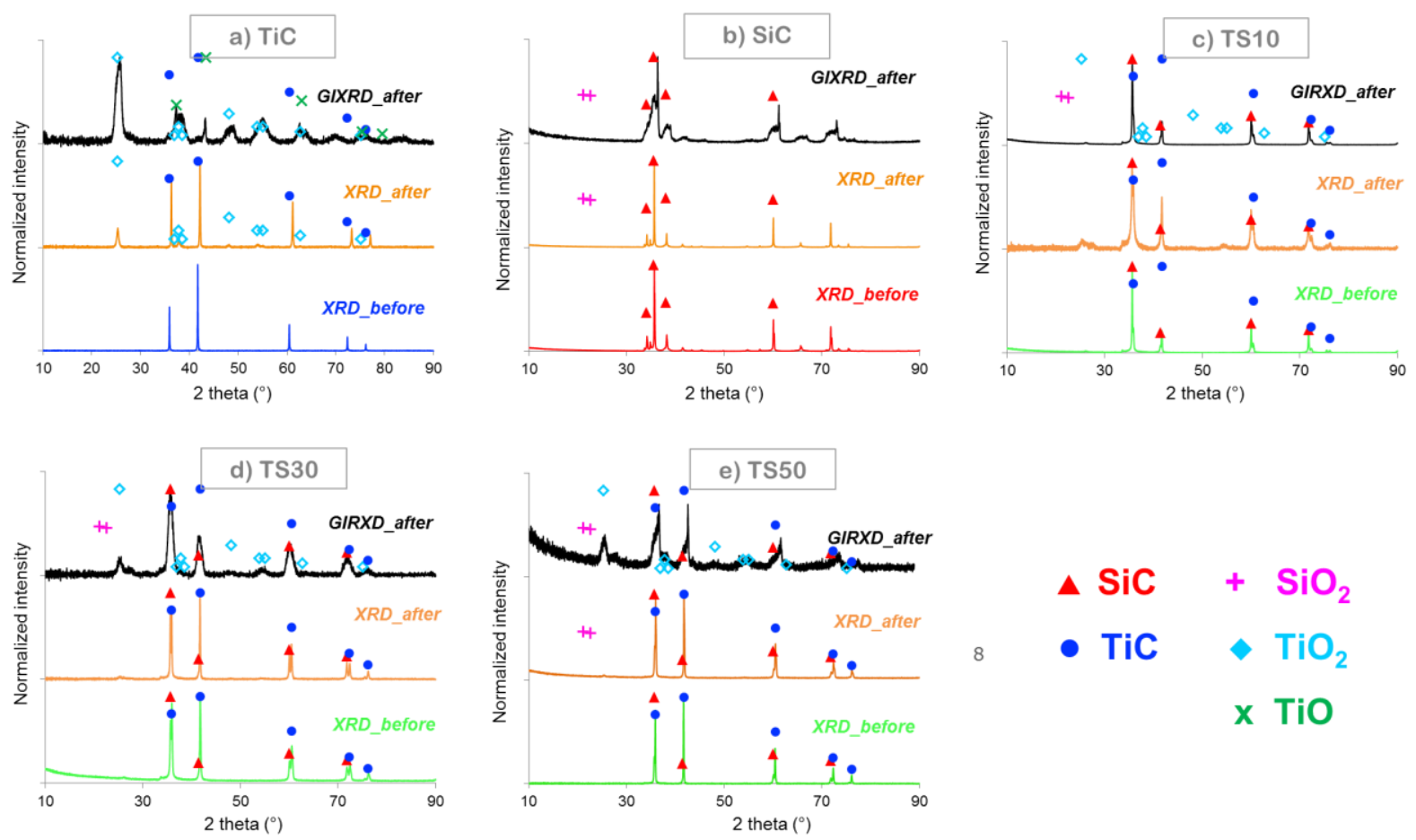

Figure 5: Grazing Incident and classical X-rays diffractograms of the samples before and after heating at 500 ${ }^{\circ} \mathrm{C}$ of a) pure $\left.\mathrm{SiC}, b\right)$ pure $\left.\mathrm{TiC}, c\right) \mathrm{TS} 10$, d) TS30 and e) TS50. The position of $\mathrm{SiO}_{2}$ main peaks is given as an indication to show that this phase is not detected. The comparison between the X-rays diffractograms of all

In order to evaluate the oxidation resistance of the samples, thermogravimetric analyses (TGA) were performed at $1000{ }^{\circ} \mathrm{C}$ during $20 \mathrm{~h}$ under air on material pieces (Figure 6-a). The oxidation degree (\%ox) was calculated considering the following oxidation reactions (4 and 5) [35, 47]. The mass variation due to carbon oxidation was neglected and the detailed calculation is reported in SI 4.

$$
\mathrm{TiC}+2 \mathrm{O}_{2} \leftrightarrow \mathrm{TiO}_{2}+\mathrm{CO}_{2}
$$

$$
\mathrm{SiC}+2 \mathrm{O}_{2} \leftrightarrow \mathrm{SiO}_{2}+\mathrm{CO}_{2}
$$

After TGA analysis, the pure TiC sample is highly oxidized, up to $79 \%$ while only $6.2 \%$ of pure $\mathrm{SiC}$ is oxidized. The composites are less oxidized than the pure samples and their \%ox increases with the $\mathrm{TiC}$ content. As pure $\mathrm{SiC}$ has a lower relative density than the other samples (74 \% compared to $>90 \%$ ), the oxygen diffusion is favored which could induce the increase

255 of the oxidation degree. Indeed, similar TGA measurements were conducted on TiC materials 256 with various relative densities from a previous study [38]. The results reported in supporting 257 information (SI 5) show that the weight gain increases when the relative density of the material 258 decreases. 
259 To evaluate the oxidation resistance of these samples over longer durations, sample pieces were 260 exposed to air in a furnace at $1000{ }^{\circ} \mathrm{C}$ during 9 days. The oxidation percentage was evaluated 261 by weighting measurements before and after oxidation (Figure 6-b). After their oxidation during $26220 \mathrm{~h}$ in the TGA apparatus and during 9 days in a furnace, the oxidized samples were embedded 263 in a resin and polished to study their cross-sections by SEM-EDX. The most meaningful EDX 264 mapping are reported in Figure 7-a) and the other ones are presented in SI 6.

265

a)

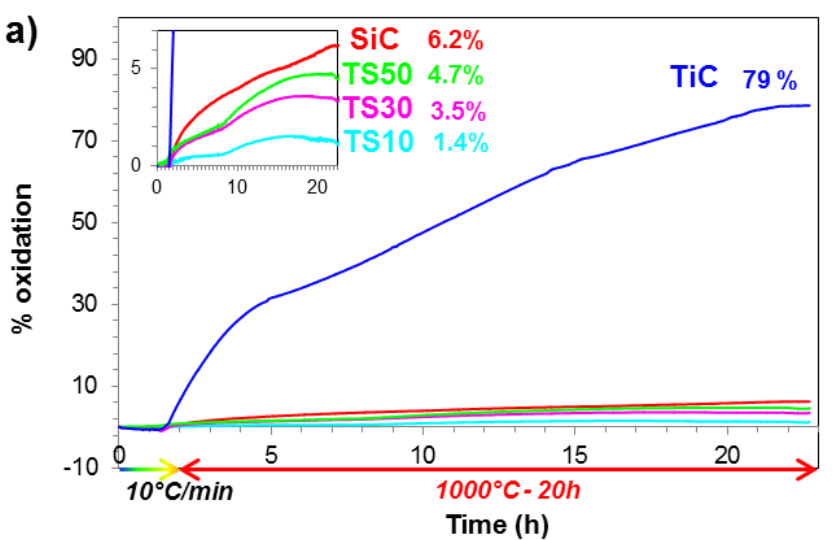

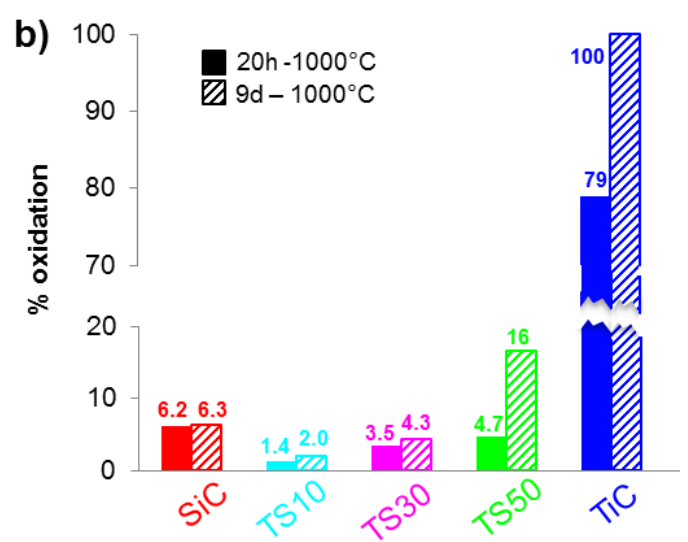

Figure 6: a) oxidation \% as a function of time during TGA measurement $\left(10^{\circ} \mathrm{C} . \mathrm{min}^{-1}\right.$ heating up to $1000{ }^{\circ} \mathrm{C}$

268 followed by a $20 \mathrm{~h}$ dwell at $1000^{\circ} \mathrm{C}$ ). b) Apparent oxidation percentage after $20 \mathrm{~h}$ and 9 days of oxidation under air at $1000{ }^{\circ} \mathrm{C}$. The error is about $10^{-3} \%$ due to the precision of the weighting measurements. 

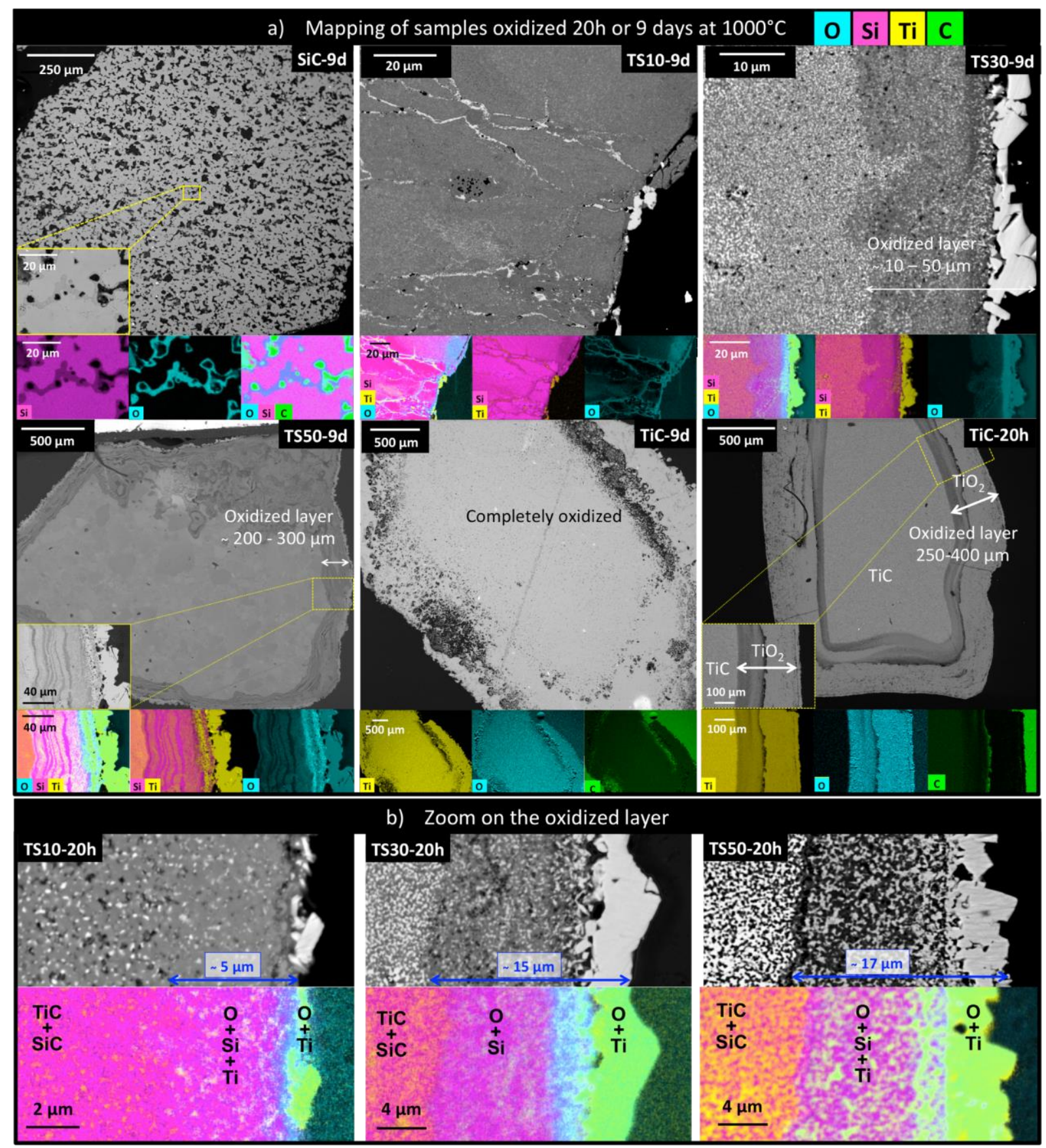

273 Figure 7: SEM-EDX mapping of polished cross sections of a) all samples after 9 days at $1000{ }^{\circ} \mathrm{C}$, and pure TiC

274 after $20 \mathrm{~h}$ at $1000^{\circ} \mathrm{C}$. b) Zoom on the oxidized layer formed on TS10, TS30, and TS50 after $20 \mathrm{~h}$ at $1000{ }^{\circ} \mathrm{C}$.

276 After $20 \mathrm{~h}$ or 9 days at $1000^{\circ} \mathrm{C}$, the pure $\mathrm{SiC}$ sample presents oxidized areas covering the pore 277 walls, even up into the center of the material (Figure 7-a). The thickness of this oxidized layer 278 and the ox\% are similar after $20 \mathrm{~h}$ and 9 days (Figure 6-b), which implies that the oxidation 279 layer is protective. After $20 \mathrm{~h}$ at $1000{ }^{\circ} \mathrm{C}$, the pure $\mathrm{TiC}$ sample presents an oxidized layer with 280 a thickness of about $250-400 \mu \mathrm{m}$, surrounding the TiC pristine core. This layer is divided into 
two sublayers, the outer tends to peel as evidenced by a $\mathrm{C}$ enrichment at the interface due to the

282 resin penetration. The inner layer is continuous but not protective since after 9 days at $1000{ }^{\circ} \mathrm{C}$, the sample is completely oxidized (Figure 6-b and Figure 7-a).

284 In the case of TS50 sample, after 20h the oxidation layer is continuous and much thinner than that of the pure TiC (about $17 \mu \mathrm{m}$ ) (Figure 7-b and SI 6). After 9 days of oxidation, the layer has grown to reach an average thickness of 200-300 $\mu \mathrm{m}$, it presents several demarcations oriented parallel to the surface. These demarcations are formed by areas depleted in Ti and $\mathrm{O}$, mainly composed by Si and C (SI 6). The apparent ox\% is three times higher after 9 days than after $20 \mathrm{~h}$. In the case of the TS30 sample, the oxidation layers are continuous and have close thickness after $20 \mathrm{~h}$ or 9 days at $1000{ }^{\circ} \mathrm{C}(10-20 \mu \mathrm{m})$. The ox\% has not evolved from $20 \mathrm{~h}$ to 9 days at $1000{ }^{\circ} \mathrm{C}$.

292 The oxidation layer of TS10 sample is not continuous, some Ti-O containing aggregates are 293 present on the surface, and on the domain boundaries. These domains illustrate changes in 294 composition ( $\mathrm{Ti} / \mathrm{Si}$ proportion) and/or porosity in the direction of the sample thickness, 295 similarly to those observed in the direction of the sample diameter, and reported in Figure 2. 296 Depending on their composition and porosity, these domains can form oxidized pockets. After 2979 days of oxidation, the apparent ox \% has increased from 1.4 to $2 \%$. The oxidation layer after $29820 \mathrm{~h}$ is about $5 \mu \mathrm{m}$ thick.

299 For all nanocomposites, EDX mapping at high magnification are reported in Figure 7-b. The 300 oxidized layer can be divided into several sublayers with changes in composition. The outer 301 sub-layer is composed of $\mathrm{Ti}$ and $\mathrm{O}$, without $\mathrm{Si}$. The inner sub-layer is partly depleted in $\mathrm{Ti}$, and 302 enriched in $\mathrm{Si}$ and $\mathrm{O}$. As Underneath this oxidized layer, pristine SiC-TiC appears to be undamaged.

\section{Discussion}

\subsection{Effects of the TiC proportion on the optical properties}

The expected TiC-SiC overall proportions have been confirmed by SEM-EDX and XRF. SEM observations confirmed that the $\mathrm{TiC}$ grains have the same size in all samples but they tend to form aggregates when increasing the TiC content (Figure 2).

310 Before heating, the spectral reflectance at room temperature increases with the increase in the 311 TiC proportion in the entire range of analyzed wavelengths (Figure 3 and SI 3). From the 312 spectral reflectance curves measured at various incident angles, the total solar absorptance $(\alpha)$ and the hemispherical thermal emittance $\left(\varepsilon_{H}\right)$ were calculated using equations (1), (2) and (3). 
314 The results are reported as a function of the $\mathrm{TiC}$ content in Figure 8-a. It appears that the 315 increase in the TiC content induces a decrease in both the absorptance $(\alpha)$ and the hemispherical 316 emittance $\left(\varepsilon_{H}\right)$, leading to a great increase in the spectral selectivity $\left(\alpha / \varepsilon_{H}\right)$, as observed 317 previously for TiC-SiC composites [38]. This increase is stronger between $30 \%$ and $50 \%$ of 318 TiC than in the rest of the composition ranges.

319 During heating, the near-normal spectral IR reflectance has been measured at various 320 temperatures (Figure 3) leading to the calculation of the total directional thermal emittance $\left(\varepsilon_{8^{\circ}}\right)$, 321 as reported in Figure 8-d). In all cases, the directional emittance increases with the heating 322 temperature and the effect is higher when the $\mathrm{TiC}$ proportion increases. The increase in 323 emittance with the measured temperature has already been reported for other borides and 324 carbides $[20,48]$.

325 After heating and cooling, the increase in emittance is not conserved for the pure SiC sample since the hemispherical emitance values measured at room temperature before and after heating 327 are the same (Figure 8-b). However, in the presence of $\mathrm{TiC}$ (pure $\mathrm{TiC}$ and composites), there is 328 a difference between the absorptance and emittance values measured at room temperature 329 before, and after heating (Figure 8-c).
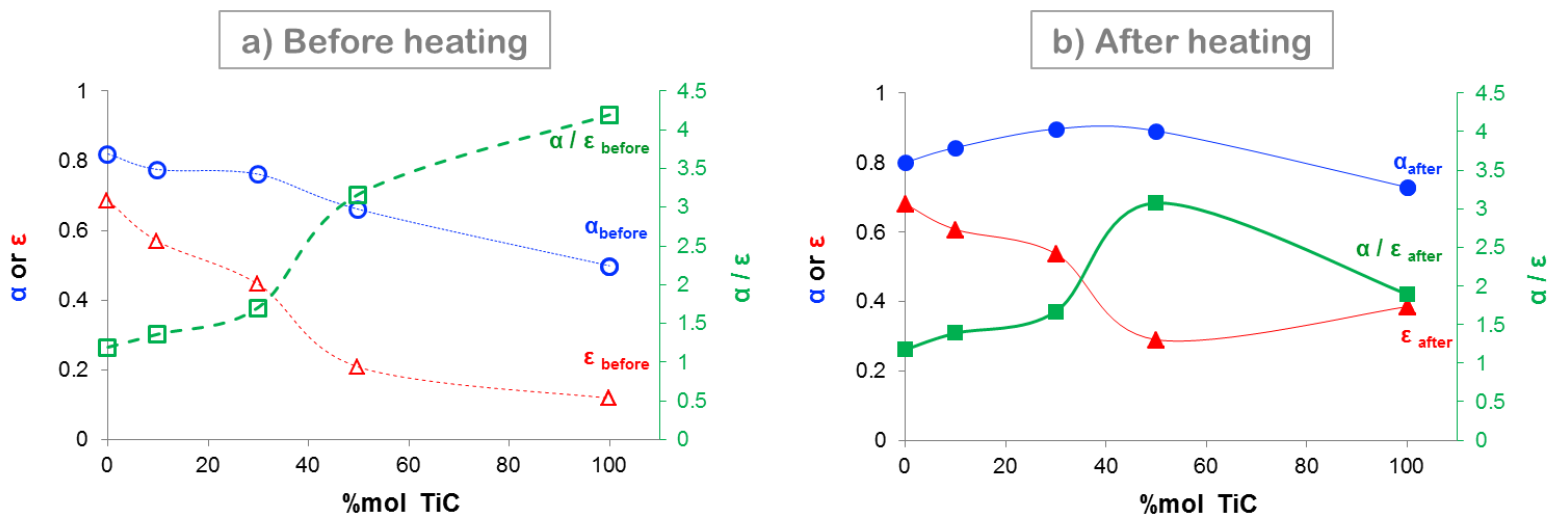

c) After / Before heating

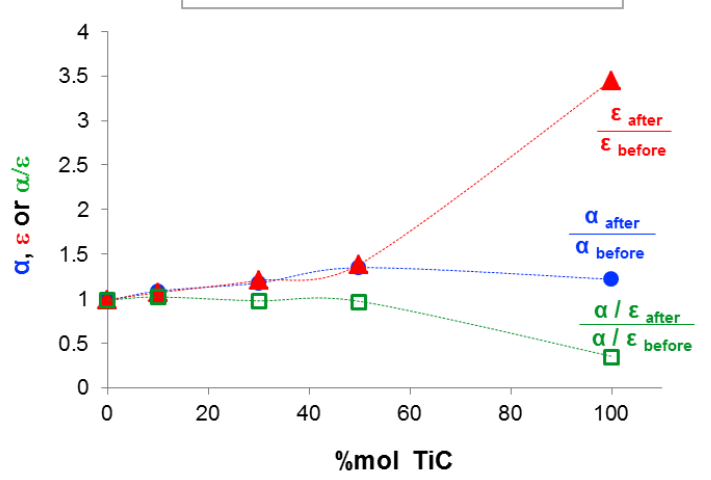

d) During heating

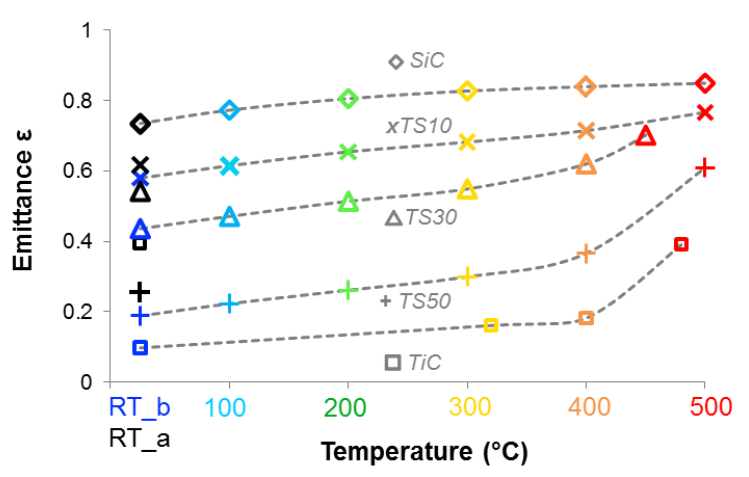



measurements a) before heating, $b$ ) after heating and c) the ratio between them, as a function of the TiC proportion $(\% m o l) ; d)$ directional emittance $\left(\varepsilon_{8^{\circ}}\right)$ as a function of the temperature of measurement.

The hemispherical emittance after heating is a little higher than before heating for all the nanocomposites and much higher for the pure TiC sample. After heating, the hemispherical emittance is even higher for the pure TiC sample than for the TS50 nanocomposite (Figure 8b). For all samples except the pure $\mathrm{SiC}$, the absorptance calculated from room temperature measurements has increased after heating (Figure 8-c). The evolution of the absorptance after heating as a function of the TiC content shows a bell shaped curve with a maximum for TS50 nanocomposite. As both the absorptance and the hemispherical emittance increase after heating, the selectivity does not change for all samples, except the pure TiC. For the latter, the increase in hemispherical emittance is too high to be compensated by the increase in absorptance, thus the selectivity decreases. These changes on the optical properties can be linked to the surface modifications observed by SEM (Figure 4). The TiC grains at the surface are oxidized, and the presence of $\mathrm{TiO}_{2}$ and $\mathrm{TiO}$ is detected by XRD and GIXRD (Figure 5). An increase in the surface roughness is also reported, which could be linked to the volume gain due to the oxidation of $\mathrm{TiC}$ into $\mathrm{TiO}_{2}$, and to swelling due to carbon release. Previous work showed that the increase in surface roughness induces an increase in both the absorptance and the emittance [38].

\subsection{Effects of the $\mathrm{SiC}$ content on the oxidation resistance}

The low relative density and high open porosity of pure SiC sample favored O penetration and produced an oxidized layer on the pore walls, even up into the center of the sample. This correlation between low relative density and high oxidation degree is confirmed by TGA oxidation procedure applied to several TiC materials with various relative densities (SI 5). However, the thickness of the oxidized layer and the \%ox calculated from weight gain did not increase between $20 \mathrm{~h}$ and 9 days. Therefore, the oxidation layer appears to be protective. According to the litterature, this layer could be $\mathrm{SiO}_{2}$, as it was reported during the passive oxidation of $\mathrm{SiC}$ at temperatures below $1400{ }^{\circ} \mathrm{C}[47,49,50]$. For temperatures above $1400{ }^{\circ} \mathrm{C}$, $\mathrm{SiC}$ endures active oxidation releasing gaseous $\mathrm{SiO}$.

363 Pure TiC sample is completely oxidized after 9 days at $1000{ }^{\circ} \mathrm{C}$. The oxidation of $\mathrm{TiC}$ into $\mathrm{TiO}_{2}$ and $\mathrm{TiO}$ has already been widely reported in the literature $[35,39,51-53]$. Depending on the 
particle size, the temperature of oxidation of TiC can vary, nevertheless it starts around $380{ }^{\circ} \mathrm{C}$, and follows four stages [52]. First $\mathrm{TiC}$ is oxidized into oxycarbide $\mathrm{TiC}_{\mathrm{x}} \mathrm{O}_{(1-\mathrm{x})}$, then it forms suboxides ( $\mathrm{TiO}, \mathrm{Ti}_{3} \mathrm{O}_{5}$ or $\left.\mathrm{Ti}_{4} \mathrm{O}_{9}\right)$, followed by the formation of anatase $\left(\mathrm{TiO}_{2}\right)$, and finally it evolves toward rutile $\left(\mathrm{TiO}_{2}\right)$. The oxidation layer is usually divided into two sub-layers; $\mathrm{TiO}_{2}$ on top of sub-oxides like $\mathrm{Ti}_{3} \mathrm{O}_{5}, \mathrm{Ti}_{4} \mathrm{O}_{7}$. These two sub-layers are present on the pure $\mathrm{TiC}$ sample oxidized after $20 \mathrm{~h}$ but not after 9 days. The oxidation kinetics of $\mathrm{TiC}$ depend on the diffusion of $\mathrm{O}$ through the material, which explains the substoichiometry of the inner layer and the higher oxidation degree for less dense samples $[35,54,55]$. After 9 days of oxidation, $\mathrm{O}$ has diffused enough through the material to produce a single layer of $\mathrm{TiO}_{2}$.

In the case of the composites, the oxidation layer can be divided into two sub-layers. $\mathrm{Ti}$ is concentrated at the surface, forming $\mathrm{TiO}_{2}$ aggregates for the lowest $\mathrm{Ti}$ composition (TS10) and a continuous layer of $\mathrm{TiO}_{2}$ for richer ones (TS30 and TS50). Underneath, the inner layer is highly depleted in $\mathrm{Ti}$, which means that Ti has diffused somehow toward the surface during the oxidation. The inner $\mathrm{Si}, \mathrm{O}$ rich layer could be $\mathrm{SiO}_{2}$. This layer appears to form a continuous and protective barrier for samples with enough Si (TS10 and TS30) but not for the composition with lower Si content (TS50). These results are consistent with the oxidation study of $\mathrm{TiC} / \mathrm{SiC}$ composites by Banu et al. [39]. They observed embedded TiC particles in a SiC matrix, with the presence of $\mathrm{SiO}_{2}$ and $\mathrm{TiO}_{2}$ after the oxidation at $750{ }^{\circ} \mathrm{C}$ under static air. Furthermore, Baux et al. synthesized porous TiC-SiC ceramics by Chemical Vapor Infiltration (CVI) of SiC into cellular TiC structures [56]. After 10 hours of oxidation at $1000^{\circ} \mathrm{C}, \mathrm{TiC}$ was oxidized into $\mathrm{TiO}_{2}$ and suboxides in the core of the sample, whereas $\mathrm{TiC}$ parts located near the surface were protected from oxidation by a layer of $\mathrm{SiC}$. They concluded that this difference was due to the inhomogenous penetration of SiC deposed by CVI. However, they did not report the oxidation of $\mathrm{SiC}$ into $\mathrm{SiO}_{2}$ nor the presence of any Ti-depleted layer underneath. To our knowledge, the formation at $1000{ }^{\circ} \mathrm{C}$ of a $\mathrm{SiO}_{2}$ layer underneath a $\mathrm{TiO}_{2}$ crust has not been reported in the literature. Therefore, ongoing work is conducted to study in more detail the processes involved in the formation of these sub-layers during TiC-SiC composite oxidation.

\subsection{Comparision with other materials}

393 The literature reports several studies concerning the optical properties of UHTCs and especially 394 of borides and carbides. Our pure TiC sample, with a spectral selectivity of 5.0, approaches the 395 best one reported so far: dense $\mathrm{LaB}_{2}(\alpha / \varepsilon=6.4$ [57]). The spectral selectivity of TS30 and TS50 396 composites (1.7 and 3.2) are superior to pure $\mathrm{SiC}$ (1-1.1 [58] and this study). They are in the 397 same range as $\mathrm{MoSi}_{2}$ added carbides (2.2 for $\mathrm{HfC}, 2.4$ for $\mathrm{ZrC}$, and 2.8 for $\mathrm{TaC}$ [59]), pure 
borides (2.5 for $\mathrm{HfB}_{2}, 3.9$ for $\mathrm{ZrB}_{2}$ and 4.0 for $\mathrm{TaB}_{2}$ [22, 58], 2.2 for $\mathrm{TiB}_{2}$ [60]), and composites

399 (2.2 for $\mathrm{HfB}_{2}-\mathrm{SiC}$ and 2.8 for $\mathrm{HfB}_{2}-\mathrm{HfC}-\mathrm{SiC}$ [61]). This comparison is given as an indication 400 since the spectral selectivity values originate from emittance measurements at different 401 temperatures. Indeed, it has been reported that the emittance measured at room temparature is 402 usually underestimated compared to the one measured at higher temperatures [12], thereby 403 impacting the spectral selectivity. However, in all cases, the samples did not experienced 404 oxidation since measurements were conducted at room temperature or at high temperature 405 measurements under vaccum or inert atmosphere.

406 The optical properties of UHTCs after exposition to oxidation are little studied so far. $\mathrm{TaB}_{2}$ 407 sumitted to helium or air atmosphere during $20 \mathrm{~min}$ at $827{ }^{\circ} \mathrm{C}$ loses completely its spectral selectivity [62], the spectral selectivity of $\mathrm{ZrB}_{2}+10 \% \mathrm{MoSi}_{2}$ decreases toward 1, and reaches the one of pure $\mathrm{SiC}$ after heating up to $1200{ }^{\circ} \mathrm{C}$ [63]. The results obtained for $\mathrm{HfB}_{2}-\mathrm{SiC}$ composite are better since the spectral selectivity after oxidation at $927^{\circ} \mathrm{C}$ during $5 \mathrm{~h}$ is still of 1.3 (compared to 2.2 before oxidation) and the addition of $\mathrm{HfC}$ in this $\mathrm{HfB}_{2}-\mathrm{SiC}$ composite did not improve the results $(\alpha / \varepsilon=0.6$ after oxidation), probably because the amount of $\mathrm{SiC}$ was too 413 low [61]. In this context, our TiC-SiC composites are quite performant since TS30 and TS50 414 samples have a spectral selectivity of 1.7 and 3.1 after oxidation at $500^{\circ} \mathrm{C}$. Even though these values were obtained at lower temperatures, the oxidation tests at $1000{ }^{\circ} \mathrm{C}$ revealed the

416 formation of a protective $\mathrm{SiO}_{2}$ layer which suggests that the TiC-SiC composites could keep 417 their interesting spectral selectivity at high temperatures.

\section{Conclusion}

420 This study assessed both the optical properties and the oxidation resistance of SiC-TiC nanocomposite densified materials while heating up to $500{ }^{\circ} \mathrm{C}$. The effects of the $\mathrm{TiC}$ proportion (10 to $50 \%$ at) were studied and compared to pure $\mathrm{TiC}$ and $\mathrm{SiC}$ samples. The spectral selectivity was found to increase with the $\mathrm{TiC}$ content due to a high decrease in emittance and despite a low decrease in absorptance. The samples were heated up to $500{ }^{\circ} \mathrm{C}$ to measure the reflectance in the 1.25 to $25 \mu \mathrm{m}$ wavelength range, and determine their optical properties at various temperatures. The emittance increases with the heating temperature. After heating, the pure $\mathrm{SiC}$ sample remains unoxidized, whitout any changes in its optical properties, while pure TiC sample experiences severe oxidation and high decrease in its spectral selectivity. The composites are also partly oxidized, and more severly as the $\mathrm{TiC}$ content increased. The oxidation of $\mathrm{TiC}$ grains $\mathrm{TiO}_{2}$, leads to an increase in the surface roughness which induces an 
increase in both the emittance and the absorptance. Contrary to the pure TiC sample, for the composites, the increase in emittance is compensated by the increase in the absorptance. Therefore, the selectivity of the composites remains the same after exposure to air at $500{ }^{\circ} \mathrm{C}$. Oxidation tests at $1000{ }^{\circ} \mathrm{C}$ during $20 \mathrm{~h}$ and 9 days confirmed the dramatic TiC sensitivity to oxidation and the good oxidation resistance of SiC. The TiC-SiC composites form an oxidized layer mainly composed of a $\mathrm{TiO}_{2}$ outer sub-layer and $\mathrm{a} \mathrm{SiO}_{2}$ inner sub-layer. The latter appears to be protective when the Si content is high enough (70 at\% at least). According to all these results, the $30 \% \mathrm{TiC}-70 \% \mathrm{SiC}$ composite seems to display both high spectral selectivity and satisfactory oxidation resistance, which are required properties for solar absorber applications.

\section{Conflicts of interest}

There are no conflicts to declare.

\section{Acknowledgments}

This work was funded by the National Agency for Research (ANR) of the French State, in the framework of the CARAPASS project (award $n^{\circ}$ ANR-16-CE08-0026) and of the French "Investments for the future" program managed by ANR under contracts ANR-10-LABX-2201-SOLSTICE and ANR-10-EQPX-49-SOCRATE. We wish to thank Renaud Podor and Joseph Lautru for SEM imaging, Bruno Corso for XRD assistance, Cyrielle Rey for furnace assistance, Jeremy Causse for XRF measurements, and Christophe Escape and Jose Maria Osorio for their help in reflectometry measurements.

\section{References}

1. Granqvist, C.G., Solar energy materials. Advanced Materials, 2003. 15(21): p. 1789-

2. Tian, Y. and C.Y. Zhao, A review of solar collectors and thermal energy storage in solar thermal applications. Applied Energy, 2013. 104: p. 538-553.

3. Spitz, J., Selective surfaces for high-temperature solar photothermal conversion. Thin Solid Films, 1977. 45(1): p. 31-41.

4. Spitz, J. and D. Mazierebezes, Selective materials for solar-energy photothermal conversion. Journal of Optics-Nouvelle Revue D Optique, 1984. 15(5): p. 325-332.

5. Bogaerts, W.F. and C.M. Lampert, Materials for photothermal solar-energy conversion. Journal of Materials Science, 1983. 18(10): p. 2847-2875.

6. Lampert, C.M., Coatings for enhanced photo thermal energy collection .1. Selective absorbers. Solar Energy Materials, 1979. 1(5-6): p. 319-341.

7. Agrafiotis, C.C., et al., Evaluation of porous silicon carbide monolithic honeycombs as volumetric receivers/collectors of concentrated solar radiation. Solar Energy Materials and Solar Cells, 2007. 91(6): p. 474-488. 
8. Burlafinger, K., A. Vetter, and C.J. Brabec, Maximizing concentrated solar power (CSP) plant overall efficiencies by using spectral selective absorbers at optimal operation temperatures. Solar Energy, 2015. 120: p. 428-438.

9. Sani, E., et al., Ultra-High Temperature Ceramics for solar receivers: spectral and high-temperature emittance characterization. Journal of the European Optical SocietyRapid Publications, 2012. 7.

10. Blau, H.H. and J.R. Jasperse, Spectral emittance of refractory materials. Applied Optics, 1964. 3(2): p. 281-\&.

11. Mercatelli, L., M. Meucci, and E. Sani, Design and test of a new facility for assessing spectral normal emittance of solid materials at high temperature, in Optical Components and Materials Xiii, S. Jiang and M.J.F. Digonnet, Editors. 2016.

12. Mercatelli, L., M. Meucci, and E. Sani, Facility for assessing spectral normal emittance of solid materials at high temperature. Applied Optics, 2015. 54(29): p. 8700-8705.

13. Sani, E., et al., Optical properties of black and white ZrO2 for solar receiver applications. Solar Energy Materials and Solar Cells, 2015. 140: p. 477-482.

14. Sani, E., et al., Optical properties of boride ultrahigh-temperature ceramics for solar thermal absorbers. Journal of Photonics for Energy, 2014. 4.

15. Sciti, D., et al., Tantalum diboride-based ceramics for bulk solar absorbers. Solar Energy Materials and Solar Cells, 2014. 130: p. 208-216.

16. Sani, E., et al., Porous and dense hafnium and zirconium ultra-high temperature ceramics for solar receivers. Optical Materials, 2013. 36(2): p. 163-168.

17. Sciti, D., et al., Suitability of ultra-refractory diboride ceramics as absorbers for solar energy applications. Solar Energy Materials and Solar Cells, 2013. 109: p. 8-16.

18. Sani, E., et al., Hafnium and tantalum carbides for high temperature solar receivers. Journal of Renewable and Sustainable Energy, 2011. 3(6).

19. Sani, E., et al., Ultra-refractory ceramics for high-temperature solar absorbers. Scripta Materialia, 2011. 65(9): p. 775-778.

20. Mercatelli, L., et al., Ultra-refractory diboride ceramics for solar plant receivers. Proceedings of the Solarpaces 2013 International Conference, 2014. 49: p. 468-477.

21. Sani, E., et al., Compositional dependence of optical properties of zirconium, hafnium and tantalum carbides for solar absorber applications Solar Energy, 2016. - 131(-): p. -207.

22. Sani, E., et al., Optical properties of dense zirconium and tantalum diborides for solar thermal absorbers. Renewable Energy, 2016. 91: p. 340-346.

23. Sani, E., et al., Optical properties of ZrB2 porous architectures. Solar Energy Materials and Solar Cells, 2016. 144: p. 608-615.

24. Sani, E., et al., Process and composition dependence of optical properties of zirconium, hafnium and tantalum borides for solar receiver applications. Solar Energy Materials and Solar Cells, 2016. 155: p. 368-377.

25. Antou, G., et al., Thermomechanical properties of a spark plasma sintered $\mathrm{ZrC}$-SiC composite obtained by a precursor derived ceramic route. Materials Science and Engineering a-Structural Materials Properties Microstructure and Processing, 2015. 643: p. 1-11.

26. Fahrenholtz, W.G., et al., Refractory diborides of zirconium and hafnium. Journal of the American Ceramic Society, 2007. 90(5): p. 1347-1364.

27. Wuchina, E., et al., Designing for ultrahigh-temperature applications: The mechanical and thermal properties of $H f B 2, H f C x$, HfNx, and alpha $H f(N)$. Journal of Materials Science, 2004. 39(19): p. 5939-5949.

28. Mroz, C., Zirconium diboride. American Ceramic Society Bulletin, 1994. 73(6): p. 141142. 
29. Coulibaly, M., et al., From colloidal precursors to metal carbides nanocomposites MC $(M=T i, Z r, H f$ and $\mathrm{Si})$ : Synthesis, characterization and optical spectral selectivity studies. Solar Energy Materials and Solar Cells, 2015. 143: p. 473-479.

30. Charpentier, L., et al., High temperature oxidation of Zr-and Hf-carbides: Influence of matrix and sintering additive. Journal of the European Ceramic Society, 2013. 33(1516): p. 2867-2878.

31. Charpentier, L., et al., Microstructural characterization of ZrC-MoSi2 composites oxidized in air at high temperatures. Applied Surface Science, 2013. 283: p. 751-758.

32. Onuma, A., et al., High temperature oxidation of sintered TiC in an H2O-containing atmosphere. Solid State Ionics, 2004. 172(1-4): p. 417-419.

33. Shimada, S., A thermoanalytical study on the oxidation of $\mathrm{ZrC}$ and HfC powders with formation of carbon. Solid State Ionics, 2002. 149(3-4): p. 319-326.

34. Shimada, S. and K. Mochidsuki, The oxidation of TiC in dry oxygen, wet oxygen, and water vapor. Journal of Materials Science, 2004. 39(2): p. 581-586.

35. Gherrab, M., et al., Oxidation behavior of nano-scaled and micron-scaled TiC powders under air. International Journal of Refractory Metals \& Hard Materials, 2013. 41: p. 590-596.

36. Sempere, J., et al., Thermal behavior of oxidation of TiN and TiC nanoparticles. Journal of Thermal Analysis and Calorimetry, 2011. 105(2): p. 719-726.

37. Rudneva, V.V. and G.V. Galevskii, Investigation of thermal oxidation resistance of nanopowders of refractory carbides and borides. Russian Journal of Non-Ferrous Metals, 2007. 48(2): p. 143-147.

38. Aréna, H., et al., SiC-TiC nanocomposite for bulk solar absorbers applications: Effect of density and surface roughness on the optical properties. Solar Energy Materials and Solar Cells, 2019. 191: p. 199-208.

39. Banu, N.D., et al., Identification of selective oxidation of TiC/SiC composite with X-ray diffraction and Raman spectroscopy. Chemical Papers, 2016. 70(11): p. 1503-1511.

40. Pizon, D., et al., Oxidation behavior of spark plasma sintered ZrC-SiC composites obtained from the polymer-derived ceramics route. Ceramics International, 2014. 40(3): p. 5025-5031.

41. Tripp, W.C., H.H. Davis, and H.C. Graham, Effect of an SiC addition on oxidation of ZrB2. American Ceramic Society Bulletin, 1973. 52(8): p. 612-616.

42. Deschanels, X., et al., Comparison of two soft chemistry routes for the synthesis of mesoporous carbon/beta-SiC nanocomposites. Journal of Materials Science, 2013. 48(11): p. 4097-4108.

43. Diago, M., et al., Characterization of desert sand to be used as a high-temperature thermal energy storage medium in particle solar receiver technology. Applied Energy, 2018. 216: p. 402 - 413.

44. Soum-Glaude, A., et al., Optical characterization of TiAlNx/TiAlNy/Al2O3 tandem solar selective absorber coatings. Solar Energy Materials and Solar Cells, 2017. 170: p. 254 - 262.

45. Khalil, N.Z., et al., Effect of Particle Size Distribution on SiC Ceramic Sinterability. Materials Transactions, 2015. 56(11): p. 1827-1833.

46. Lara, A., et al., Densification of additive-free polycrystalline beta-SiC by spark-plasma sintering. Ceramics International, 2012. 38(1): p. 45-53.

47. Ramberg, C.E., et al., Passive-oxidation kinetics of high-purity silicon carbide from 800 degrees to 1100 degrees $C$. Journal of the American Ceramic Society, 1996. 79(11): p. 2897-2911.

48. Sani, E., et al., Porous and dense hafnium and zirconium ultra-high temperature ceramics for solar receivers. Optical Materials, 2013. 36(2): p. 163-168. 
49. Liu, D.M., Oxidation of polycrystalline alpha-silicon carbide ceramic. Ceramics International, 1997. 23(5): p. 425-436.

50. Costello, J.A., I.S.T. Tsong, and R.E. Tressler, OXYGEN PENETRATION INTO SIC CERAMICS DURING THERMAL-OXIDATION. American Ceramic Society Bulletin, 1981. 60(3): p. 379-379.

51. Shimada, S., A thermoanalytical study of oxidation of TiC by simultaneous TGA-DTAMS analysis. Journal of Materials Science, 1996. 31(3): p. 673-677.

52. Shimada, S. and M. Kozeki, Oxidation of TiC at low-temperatures. Journal of Materials Science, 1992. 27(7): p. 1869-1875.

53. Zhang, L.H. and R.V. Koka, A study on the oxidation and carbon diffusion of TiC in alumina titanium carbide ceramics using XPS and Raman spectroscopy. Materials Chemistry and Physics, 1998. 57(1): p. 23-32.

54. Zainulin, Y.G., S.I. Alyamovsky, and G.P. Shveikin, Concerning structural mechanism of oxygen inclusion into lattice of titanium carbide. Journal of Physics and Chemistry of Solids, 1978. 39(1): p. 29-31.

55. Schuhmacher, M. and P. Eveno, Oxygen diffusion in titanium carbide. Solid State Ionics, 1984. 12(MAR): p. 263-270.

56. Baux, A., et al., Synthesis and properties of multiscale porosity TiC-SiC ceramics. Journal of the European Ceramic Society, 2019. 39(8): p. 2601-2616.

57. Sani, E., et al., Lanthanum hexaboride for solar energy applications. Scientific Reports, 2017. 7.

58. Sciti, D., et al., Suitability of ultra-refractory diboride ceramics as absorbers for solar energy applications. Solar Energy Materials and Solar Cells, 2013. 109: p. 8-16.

59. Sani, E., et al., Compositional dependence of optical properties of zirconium, hafnium and tantalum carbides for solar absorber applications. Solar Energy, 2016. 131: p. 199207.

60. Sani, E., et al., Titanium diboride ceramics for solar thermal absorbers. Solar Energy Materials and Solar Cells, 2017. 169: p. 313-319.

61. Musa, C., et al., Optical characterization of hafnium boride and hafnium carbide-based ceramics for solar energy receivers Solar Energy, 2018. 169: p. 111-119.

62. Charpentier, L. and C. Caliot, The impact of the oxidation on the optical properties of TaC. Solar Energy Materials and Solar Cells, 2017. 171: p. 16-23.

63. Silvestroni, L., et al., An overview of ultra-refractory ceramics for thermodynamic solar energy generation at high temperature. Renewable Energy, 2019. 133: p. 1257-1267.

64. Coulibaly, M., Carbures nanocomposites issus de précurseurs s ol-gel et impacts sur la sélectivité optique 2015, Montpellier. 


\section{Supporting information}

\section{SI 1: Synthesis route and material characterization devices and conditions}

\section{Synthesis}

The nanocomposites were prepared using a semi-molecular route involving hydrolysis and polycondensation of alkoxides as metal oxide precursors and sucrose as carbon source. The resulting powders were subjected to two heat treatments to decompose the sucrose and citric acid into carbon $\left(800{ }^{\circ} \mathrm{C}\right.$ Equations 1 and 2) and then for the carbothermal reduction of oxides into carbide $\left(1550{ }^{\circ} \mathrm{C}\right.$ Equation 3).

Sucrose and citric acid decomposition $-\mathrm{T}=800^{\circ} \mathrm{C}$

$$
\left\{\begin{aligned}
C_{12} \mathrm{H}_{22} \mathrm{O}_{11(s)} & \rightarrow \mathbf{1 2} \mathrm{C}_{(s)}+11 \mathrm{H}_{2} \mathrm{O}_{(g)} \\
\mathrm{C}_{6} \mathrm{H}_{8} \mathrm{O}_{7(s)} & \rightarrow \mathbf{6} C_{(s)}+4 \mathrm{H}_{2} \mathrm{O}_{(g)}+\frac{3}{2} O_{2}(g)
\end{aligned}\right.
$$

Carbothermal reduction - $\mathrm{T}=1550{ }^{\circ} \mathrm{C}$

$$
\mathrm{MO}_{2(s)}+3 \mathrm{C}_{(s)} \rightarrow \mathrm{MC}_{(s)}+2 \mathrm{CO}_{(g)}
$$

$$
R=\frac{12 * n_{C_{12} \mathrm{H}_{22} \mathrm{O}_{11}}}{3 * n_{M O_{2}}}+\frac{6 * n_{\mathrm{C}_{6} \mathrm{H}_{8} \mathrm{O}_{7}}}{3 * n_{M O_{2}}}
$$

$$
F=\frac{n_{T i}}{n_{T i}+n_{S i}}=\frac{n_{T T I P}}{n_{T T I P}+n_{T E O S}}
$$

The ratio $\mathrm{R}$ (Equation 4) quantifies the carbon content resulting from the decomposition of sucrose and citric acid according to the Equations (1) and (2). Because the decomposition of sucrose and citric acid produces not only effective carbon but also carbon gaseous species, the amount of carbon available for the carbothermal reduction is not easily predictable and varies depending on the conditions. The value of the $\mathrm{R}$ ratio leading to a stoichiometric carbothermal reaction is empirical. The values of $\mathrm{R}$ ratio are deduced according to preliminary studies [64]. The relative proportions of $\mathrm{Si}$ and $\mathrm{Ti}$ in the final composite were controlled by the $\mathrm{F}$ ratio, defined by Equation 5. The amounts of TEOS and TTIP used in the synthesis were adapted to

\begin{tabular}{|c|c|c|c|c|c|}
\hline Sample & TS10 & TS30 & TS50 & TiC & $\mathrm{SiC}$ \\
\hline $\mathbf{R}$ & 1.68 & 2.39 & 3.18 & \multicolumn{2}{|c|}{ Commercial products } \\
\hline F (\%at) & 10 & 30 & 50 & 100 & 0 \\
\hline$F^{*}(\% w t)$ & 14,3 & 39 & 60 & 100 & 0 \\
\hline $\mathbf{T}_{\text {sintering }}\left({ }^{\circ} \mathbf{C}\right)$ & \multicolumn{3}{|c|}{1750} & 1700 & 1950 \\
\hline
\end{tabular}
produce composites with increasing F ratios as described in Table 1. For the pure TiC and pure $\mathrm{SiC}$ references, commercial products supplied by Sigma Aldrich were used with a purity of 98 $\%$ and $97.5 \%$, respectively.

Table 3: Name, $R$ and $F$ ratios and sintering temperature for each sample used in this study. 
637 Archimedes method was used to measure the apparent density ( $\rho_{\text {app. }}$ ) of the sample by 638 hydrostatic weighing in water at $21^{\circ} \mathrm{C}$. The pycnometric density ( $\rho_{\text {pycno. }}$ ) of each sample was determined by helium pycnometry. The theoretical density ( $\rho_{\text {th. }}$ ) was calculated based on the average Ti / Si proportion measured by SEM-EDX and XRF analyses, and the $\mathrm{C}$ and $\mathrm{O}$ content 641 measured by elemental analyses. The relative density (D), the open and closed porosity ( $\phi_{\text {open }}$ and $\left.\phi_{\text {closed }}\right)$ were estimated according to Equations 6, 7 and 8, respectively.

$$
D=\frac{\rho_{\text {app. }}}{\rho_{\text {th. }}} \quad \text { (6) } \quad \phi_{\text {open }}=1-\frac{\rho_{\text {app. }}}{\rho_{\text {pycno. }}} \text { (7) } \quad \phi_{\text {closed }}=\frac{\rho_{\text {app. }}}{\rho_{\text {pycno. }}}-\frac{\rho_{\text {app }}}{\rho_{\text {th. }}}
$$

644 Optical interferometry was used to measure the surface roughness Ra of the samples (Fogal 645 Nanotech - Microsurf 3D). For each sample, at least six areas of $287 \mu \mathrm{m} \times 481 \mu \mathrm{m}$, were 646 analyzed to obtain an average roughness value.

\section{Morphology and composition}

648 The morphology of the samples was studied by Scanning Electron Microscopy (SEM), with an 649 FEI Quanta 200 ESEM equipped with a Field Emission Gun, and with a Tescan VEGA3 650 equipped with a W thermo-cationic gun. Energy Dispersive Spectra (EDX) were recorded using 651 a Bruker SDD 5030 detector with a $123 \mathrm{eV}$ resolution at the Mn (Ka) line. EDX was used to 652 confirm the composition of the synthesized products and to study the effects of oxidation.

653 The global Ti/Si proportion was also analyzed by X-Ray Fluorescence (XRF), using a Spectro654 Xepos apparatus with four secondary targets ( $\mathrm{Mo}, \mathrm{Al}_{2} \mathrm{O}_{3}$, Co and HOPG Bragg crystal).

655 Carbon and Oxygen analyzers (LECO CS230 and TCH600) were used to measure the total 656 carbon and oxygen contents, respectively. The samples were heated under oxygen for carbon 657 analysis, or with graphite addition under helium gas for oxygen analysis. In both cases, the 658 formation of carbon oxides was detected and quantified by infrared spectroscopy, then related 659 to the total carbon or oxygen content in the samples. Added Fe powder was used to assist the 660 combustion in the case of carbon analysis.

661 Thermogravimetric analyses (Setsys - 1750 CS Evol, Setaram) were conducted to evaluate the 662 oxidation resistance of the samples. Sample pieces weighting about $20 \mathrm{mg}$ were subjected to a $66320 \mathrm{~h}$ dwell at $100{ }^{\circ} \mathrm{C}$. The heating rates of rise and cooling were $10^{\circ} \mathrm{C} \cdot \mathrm{min}^{-1}$ and $30{ }^{\circ} \mathrm{C} \cdot \mathrm{min}^{-1}$, 664 respectively. 
666 The samples were characterized by X-Ray Diffraction (XRD) using the Bruker D8 advance 667 diffractometer equipped with lynxeye detector and using $\mathrm{Cu} \mathrm{K} \alpha$ radiation $(\lambda=1.54184 \AA)$. Data 668 were acquired in reflection geometry (parallel beam) in the $10-90^{\circ}$ ( $2 \theta$ mode) range of angles 669 with steps of $0.019^{\circ}$. Silicon powder was collected and used as standard to evaluate the 670 instrumental function. TiC compound crystallized in the cubic $\mathrm{NaCl}$ structure type in the Fm$6713 \mathrm{~m}$ space group, whereas $\mathrm{SiC}$ crystallized in the $\mathrm{ZnS}$ structure type in the F-43m space group. 672 Grazing Incident X-Ray Diffraction (GI-XRD) measurements were performed using a Bruker 673 D8 Advance diffractometer and primary optics adopting the Bragg-Brentano geometry. 674 Secondary optics were composed of long Sollers slits of $0.12^{\circ}$ and of a point detector. GI-XRD 675 patterns were collected between $10^{\circ}$ and $90^{\circ}\left(2 \theta\right.$ mode) with a $0.02^{\circ}$ step. The angular domain 676 was limited at higher angles by the beam knife-edge that equipped the reflectivity stage. The 677 incident angle, $\theta \mathrm{i}$, was fixed to a value of $0.4^{\circ}$.

\section{Optical properties}

679 Two spectrophotometers were used to measure the total spectral reflectance of the samples.

680 Over the wavelength range from 0.25 to $2 \mu \mathrm{m}$, the near-normal hemispherical $\left(R^{\perp, \cap}\right)$ reflection 681 spectrum was acquired with a $10 \mathrm{~nm}$ step using a Perkin Elmer Lambda 950 spectrophotometer. 682 This apparatus was equipped with deuterium and tungsten lamps, PMT and InGaAs detectors, and a $150 \mathrm{~mm}$ integrating sphere coated with Spectralon diffuse reflective coating. The sample

684 was illuminated at an incidence angle of $8^{\circ}$.

685 Over the wavelength range from $1.25 \mu \mathrm{m}$ to $25 \mu \mathrm{m}$, the hemispherical directional reflectance ( $686 R^{\cap, \theta}$ ) was recorded at different detection angles $\theta$ from 8 to $80^{\circ}$, using a SOC-100 HDR 687 reflectometer (Surface Optics Corporation) coupled with a Nicolet FTIR 6700 688 spectrophotometer. A gold coated calibrated specular reflectance standard was used as 689 reference during measurements (NIST calibration). The spectral range from 1.25 to $25 \mu \mathrm{m}$ was 690 covered by a FTIR equipped with InGaAs and DTGS/KBr detectors, coupled with Quartz and $691 \mathrm{KBr}$ beamsplitters, respectively. The sample was illuminated from all directions using a $700{ }^{\circ} \mathrm{C}$ 692 (973 K) blackbody as the infrared source and a $2 \pi$ imaging gold coated hemiellipsoid. The light 693 reflected by the sample at a chosen detection angle was collected by a moveable overhead 694 mirror which directed the collimated beam into the FTIR apparatus for signal treatment to 695 retrieve the reflectance spectrum. Each reflectance spectrum was derived from 64 consecutive 696 scans on the same sample. A heating plate on the sample holder enabled measurements at 
697

698

699

700

701

702

703

704

705

706

707

708

709

710

711

712

713

$$
\alpha=\frac{\int_{0.25 \mu m}^{4 \mu m}\left[1-R_{8^{\circ}}\left(\lambda, T_{a}\right)\right] \cdot G(\lambda) \cdot d \lambda}{\int_{0.25 \mu m}^{4 \mu m} G(\lambda) \cdot d \lambda}
$$

$$
\varepsilon_{\theta}(\theta, T)=\frac{\int_{1.25 \mu m}^{25 \mu m}[1-R(\lambda, T, \theta)] \cdot P(\lambda, T) \cdot d \lambda}{\int_{1.25 \mu m}^{25 \mu m} P(\lambda, T) \cdot d \lambda}
$$

$$
\varepsilon_{H}\left(T_{a}\right)=2 \int_{0}^{\pi / 2} \varepsilon_{\theta}\left(\theta, T_{a}\right) \cdot \sin \theta \cdot \cos \theta \cdot d \theta
$$

$714 \lambda$ is the wavelength $[\mu \mathrm{m}] . R_{8^{\circ}}(\lambda, T)$ and $R\left(\lambda, T_{a}, \theta\right)$ are the spectral reflectance of the sample 715 measured at various temperatures $(T)$ and a detection angle of $8^{\circ}$, or at room temperature $\left(T_{a}\right)$ 716 with a variable detection angle $\theta . G(\lambda)$ is the standard solar irradiance spectrum (ASTM-G173 717 AM1.5 direct + circumsolar) $\left[\mathrm{W} \cdot \mathrm{m}^{-2} \cdot \mu \mathrm{m}\right] . P(\lambda, T)$ is the spectral emittance (exitance) of a . blackbody at temperature $T$ derived from Planck's law $\left[\mathrm{W} \cdot \mathrm{m}^{-2} \cdot \mu \mathrm{m}\right]$. 


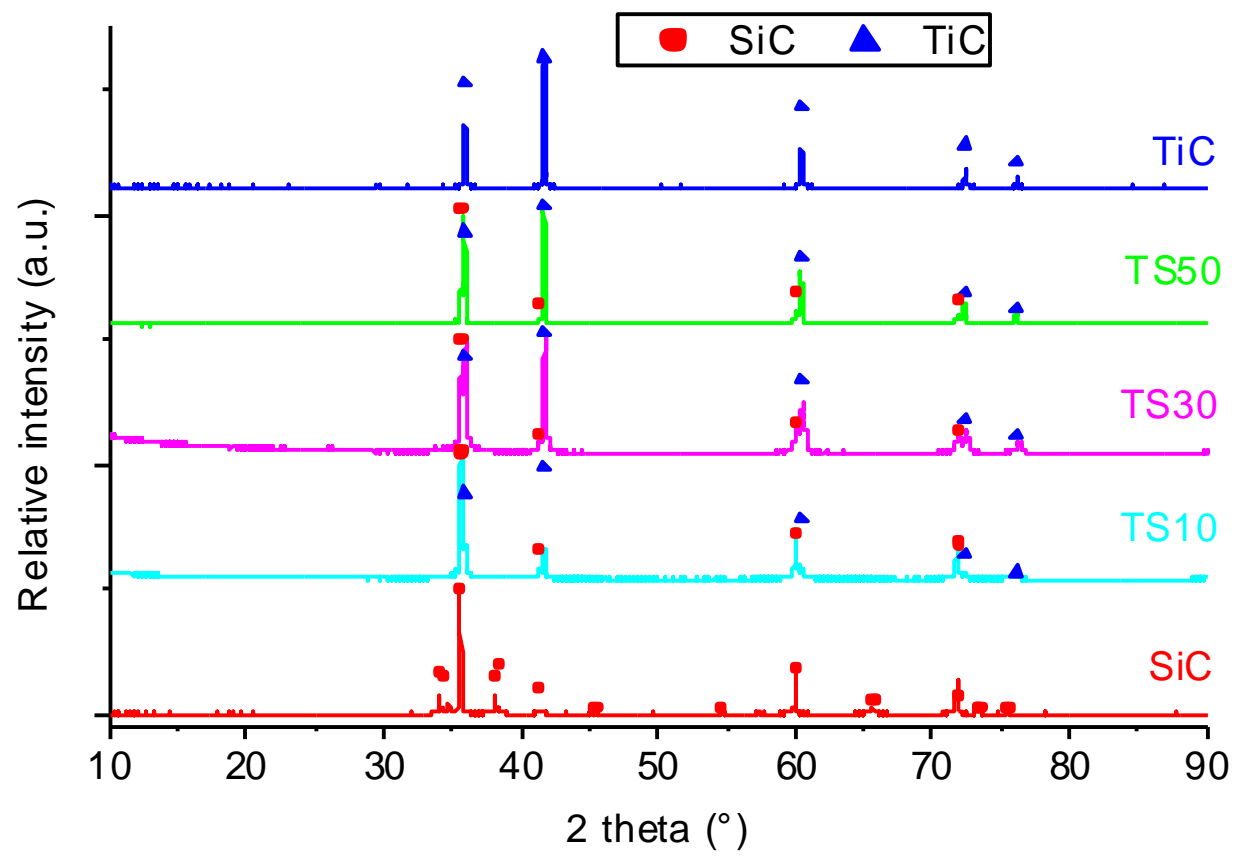

Figure 9: a) XRD diffractograms for all samples measured at room temperature before heating. 

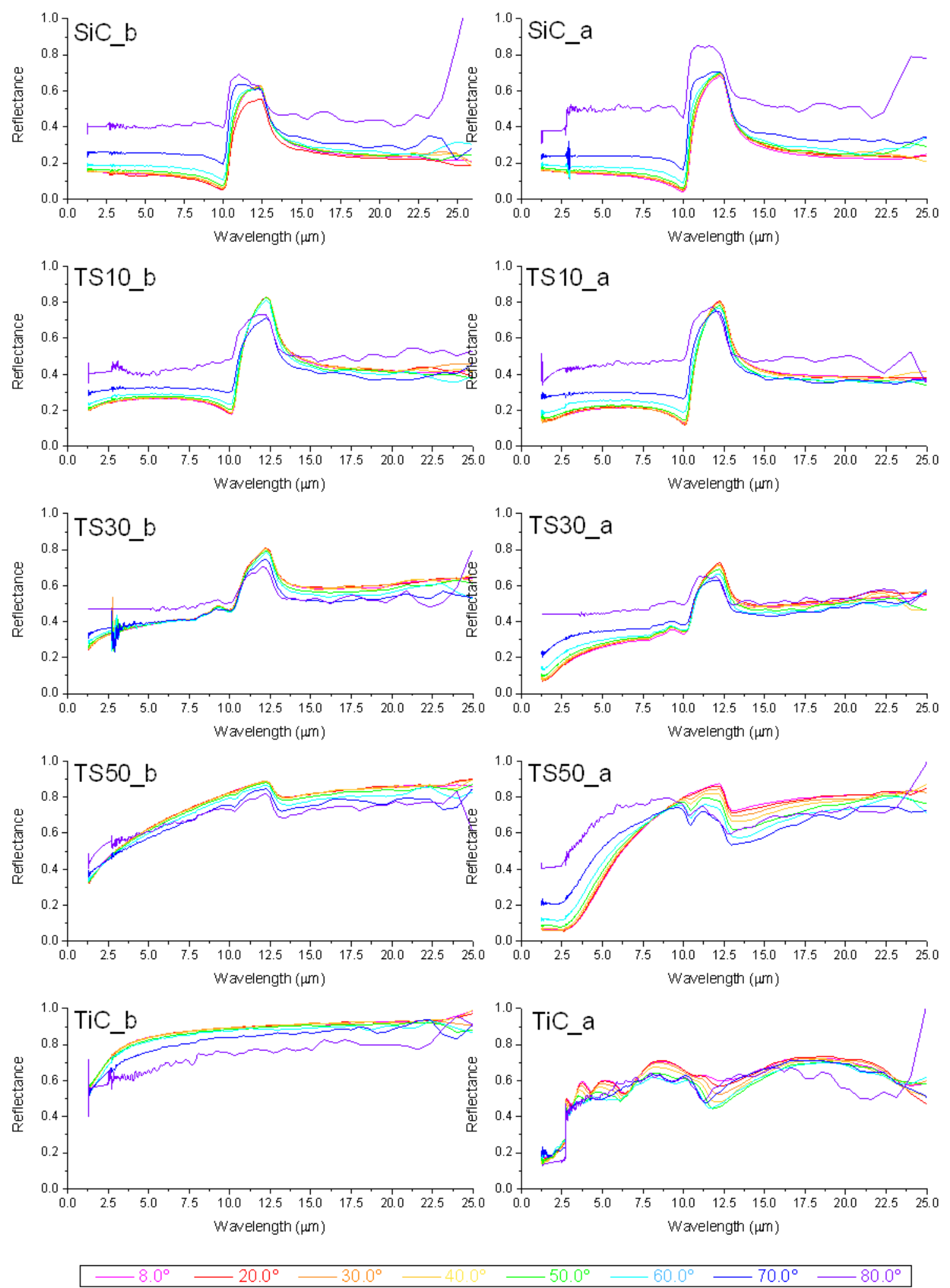
room temperature before heating (left column) and after heating (right column). 
737 From the TGA results, the relative mass gain $(\Delta \mathrm{m} / \mathrm{m})$ exp was calculated. According to the TiC 738 and $\mathrm{SiC}$ oxidation reactions 12 and 13, if $\mathrm{TiC}$ and $\mathrm{SiC}$ are completely oxidized into $\mathrm{TiO}_{2}$ and $739 \mathrm{SiO}_{2}$, the maximum relative mass gain $(\Delta \mathrm{m} / \mathrm{m})_{\max }$ would be described by Equation 14 . In this 740 calculation, the mass variation due to carbon oxidation is neglected.

$$
\begin{gathered}
\mathrm{TiC}+2 \mathrm{O}_{2} \leftrightarrow \mathrm{TiO}_{2}+\mathrm{CO}_{2} \\
\left(\frac{\Delta m}{m}\right)_{\text {max }}=\frac{M_{\text {oxides }}}{M_{\text {carbides }}}-1=\frac{\mathrm{FiC}+2 \mathrm{O}_{2} \leftrightarrow \mathrm{SiO}_{2}+\mathrm{CO}_{2}+(1-\mathrm{F}) \times \mathrm{M}_{\mathrm{SiO}_{2}}}{\mathrm{~F} \times \mathrm{M}_{\mathrm{TiC}}+(1-\mathrm{F}) \times \mathrm{M}_{\mathrm{SiC}}}-1
\end{gathered}
$$

with $\mathrm{F}$ the $\mathrm{TiC}$ molar fraction $(\% \mathrm{~mol})$ and $\mathrm{M}$ the molar mass $\left(\mathrm{g} \cdot \mathrm{mol}^{-1}\right)$. The maximum relative mass gain is $50 \%$ for pure $\mathrm{SiC}, 47.6 \%$ for TS10, $43.5 \%$ for TS30, $40.0 \%$ for TS50 and 33.3 $\%$ for pure TiC. The oxidation percentage (\%ox) is the ratio between the experimental relative mass gain and the maximum relative mass gain, as described by Equation 15:

$$
\% o x=\frac{\left(\frac{\Delta m}{m}\right)_{\text {exp }}}{\left(\frac{\Delta m}{m}\right)_{\max }} \times 100
$$

\section{SI 5: TG analyses of $\mathrm{TiC}$ samples with various densities}

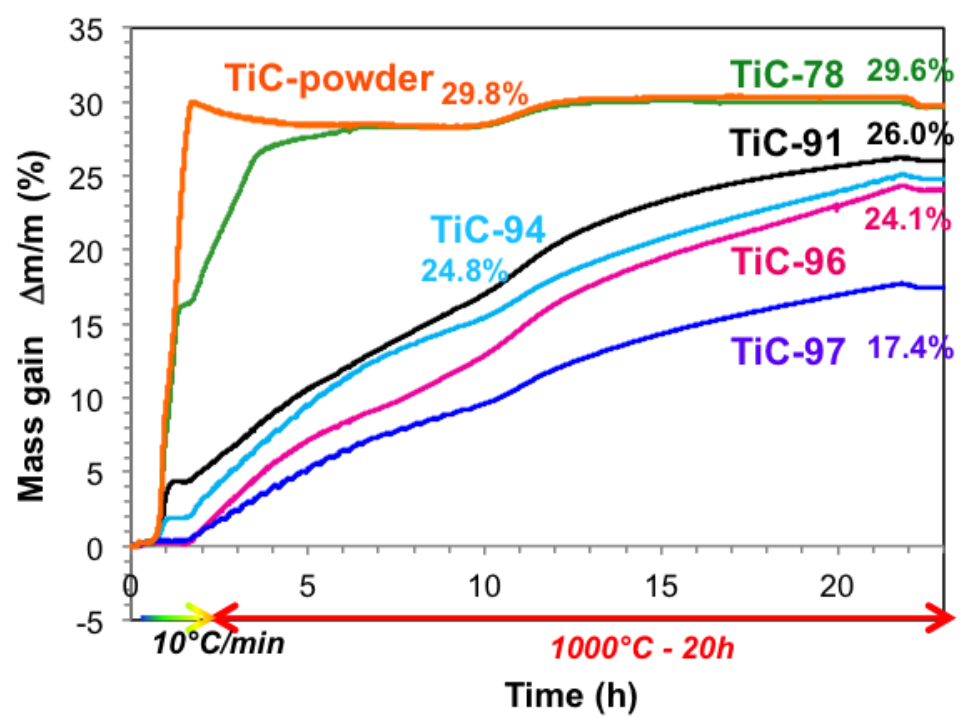

753 Figure 12: Evolution of the weight gain as a function of time during TGA measurement $\left(10^{\circ} \mathrm{C} . \mathrm{min}^{-1}\right.$ rise up to $7541000{ }^{\circ} \mathrm{C}$ followed by a $20 \mathrm{hdwell}$ at $1000^{\circ} \mathrm{C}$ ) for TiC samples with a relative density of $97 \%, 96 \%, 94 \%, 91 \%$, $75578 \%$ and powder. 
SI 6: EDX-mapping after $20 \mathrm{~h}$ or 9 days of oxidation at $1000^{\circ} \mathrm{C}$ under air.
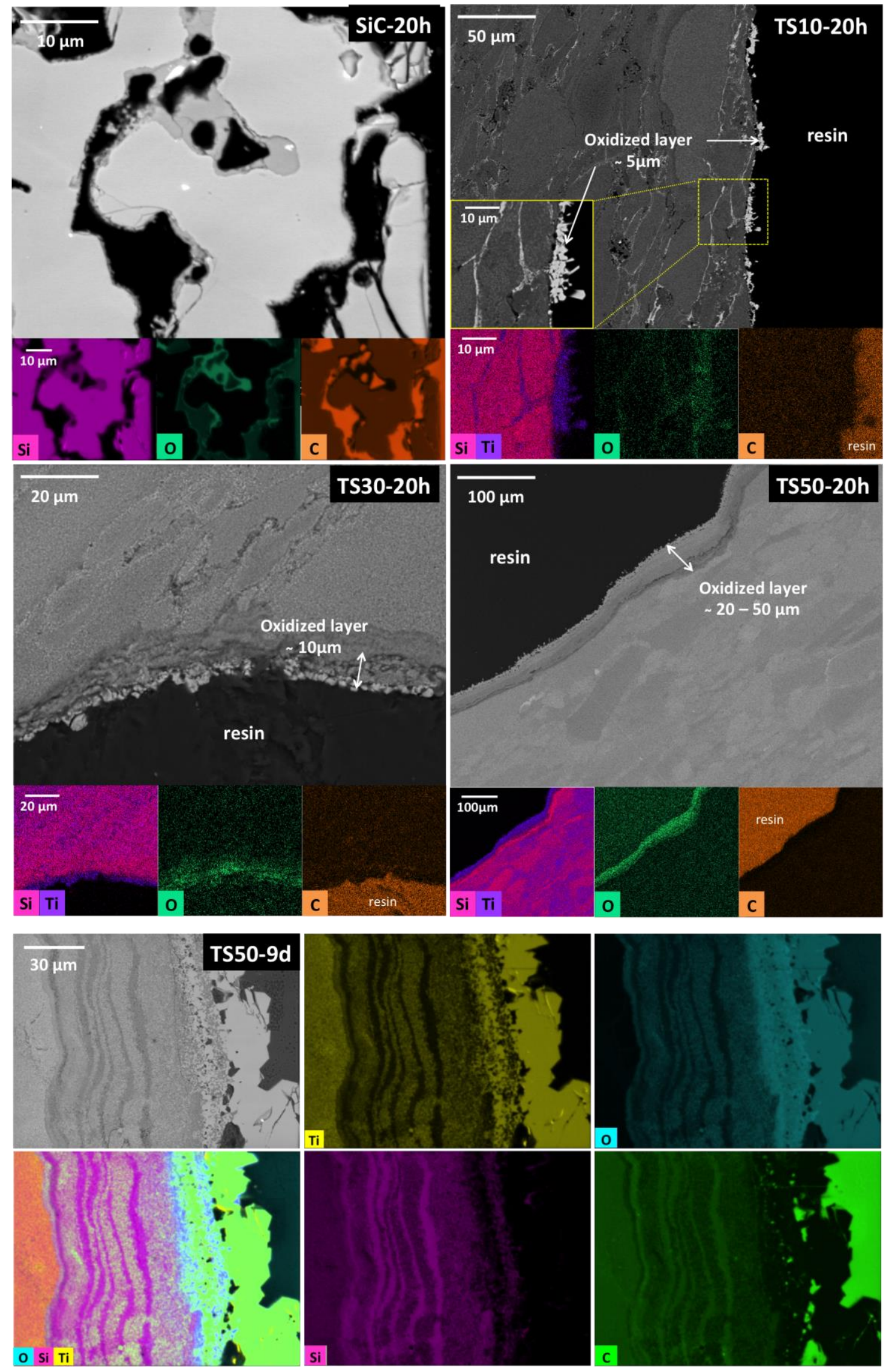

Figure 13: SEM-EDX mapping of the samples oxidized 20 h or 9 days at $1000^{\circ} \mathrm{C}$ under air. 